\title{
Regional Economic Structure and Heterogeneous Effects of Monetary Policy: Evidence From Indonesian Provinces
}

Harry Aginta ( $\sim$ harry_ag@bi.go.id)

Bank Indonesia https://orcid.org/0000-0002-0565-6207

Masakazu Someya

Nagoya University: Nagoya Daigaku

\section{Research}

Keywords: monetary transmission, economic structure, inflation, Indonesia

Posted Date: May 5th, 2021

DOI: https://doi.org/10.21203/rs.3.rs-461275/v1

License: (c) (1) This work is licensed under a Creative Commons Attribution 4.0 International License.

Read Full License

Version of Record: A version of this preprint was published at Journal of Economic Structures on January 6th, 2022. See the published version at https://doi.org/10.1186/s40008-021-00260-6. 


\title{
Regional economic structure and heterogeneous effects of monetary policy: Evidence from Indonesian provinces
}

\author{
Harry Aginta * Masakazu Someya ${ }^{\dagger}$
}

\begin{abstract}
This paper investigates the reasons for heterogeneous monetary policy effects on inflation rate across 34 Indonesian provinces. We evaluate monetary transmission by combining monetary SVAR model with factor analysis (Bernanke et al., 2005). In the first part of analysis, we demonstrate the cross-sectional variation in regional inflation responses to monetary policy shock. Spatially, most provinces in the Java-Bali region have similar responses to the national response. Moreover, provinces with a higher share of manufacturing industries in Java and Sumatra island have a response that higher than average. In the second part, we examine the role of regional economic structure in affecting two constructed measurements of monetary policy effects on regional inflation, namely total impacts and efficiency. Consistent with the literature, we find that the impacts of monetary policy across regions are significantly influenced by the economic structure of regions, represented by four variables (manufacturing and mining share to GDP, bank lending to GDP ratio, and export to GDP ratio). In addition, we also find the significant role of manufacturing growth and spatial inflation externality in shaping monetary policy impacts on regional inflation. In a similar fashion, six regional structural variables are found statistically significant in explaining regional differences of monetary policy efficiency. Our findings imply the well-functioning of interest rate, bank lending and exchange rate channels of monetary policy on regional inflation in Indonesia.
\end{abstract}

JEL Codes: E52, R11

Keywords: monetary transmission, economic structure, inflation, Indonesia

*Bank Indonesia and Graduate School of International Development, Nagoya University. Corresponding author. harry_ag@bi.go.id

${ }^{\dagger}$ Graduate School of International Development, Nagoya University. someya@gsid.nagoya-u.ac.jp 


\section{Background}

It is generally accepted that the effect of monetary policy actions is evaluated at the national level. In reality, any aggregate economic shocks - including the one from monetary policy actions - do not merely affect national aggregate but also induce regional economic activities. Since a nation is composed of diverse regions, the effect of aggregate economic shocks is not necessarily uniform across regions (Carlino and DeFina, 1998). More importantly, a body of literature suggests that monetary policy rule that ignores information at the regional level may lead to welfare losses when there are asymmetries in the transmission mechanism (De Grauwe, 2000; Gros and Hefeker, 2002).

The notion of optimal monetary policy is theoretically derived from the maximization problem of a representative agent's welfare function. In practice, monetary policy targets the national Consumer Price Index (CPI) inflation, that is, the growth rate of the cost of living for an "average" consumer. Indeed, however, empirical findings show evidence that supports the possibility that people in different parts of a country face some heterogeneity in price behavior. For instance, Cecchetti et al. (2002) use annual city-level data for 1918 to 1995 and do not find price convergence among the 19 cities in the United States, attributed to transportation costs and differences in the speed of adjustment to supply shocks. Some studies also provide evidence on heterogeneous regional price behavior in Indonesia. Using CPI data across 82 cities in Indonesia, Jangam and Akram (2019) and Aginta (2020a) find that the regional prices do not converge to a common path. Instead, they show that city prices evolve in four convergence clubs. Similarly, Aginta (2020b) uses CPI data of 34 Indonesian provinces and finds four convergence clubs of price dynamics across provinces. Such heterogeneity in regional price behaviours might lead to different responses towards a common national policy shock and has potentially significant consequences for implementing monetary policy in Indonesia.

Despite the evidence of regional price heterogeneity in Indonesia, little is known about the effects of monetary policy on regional inflation. To the best of our knowledge, only the study of Ridhwan et al. (2014) attempts to analyze the regional impacts of Indonesia's monetary policy. However, they focus on explaining the sources of variation in regional output responses to monetary policy shocks. Therefore, as well as complementing the scarce study on regional impacts of monetary policy in Indonesia, this paper is the first study that analyzes different regional inflation responses to monetary policy actions.

Our paper contributes to the existing literature at least in three following aspects. First, we scrutinize regional asymmetries of monetary policy transmission on regional inflation and evaluates the role of regional structural characteristics towards the asymmetries. Our focus on analyzing regional inflation is consistent with Indonesia's central bank's mandate to maintain rupiah stability, reflected in inflation. ${ }^{1}$ Given this mandate, it is crucial for the central bank to understand how regional economic structure affects monetary policy transmission on inflation rate in the entire archipelagos. Second, we combine the standard structural vector autoregression (VAR) model with factor analysis (Factor-Augmented VAR or FAVAR) to exploit a more extensive data set. Unlike general VARs model that might not capture the behavior of complex economic variables involved in monetary transmission mechanism, the FAVAR model proposed by Bernanke et al. (2005) allows a better identification of the monetary policy shock. Moreover, it also enables the use of unlimited variables to proxy theoretical constructs and helps researchers

\footnotetext{
${ }^{1}$ This mandate is explicitly stipulated in Act No.23 of 1999 concerning Bank Indonesia, as amended by Act No.3 of 2004 and Act No.6 of 2009 in Article 7.
} 
eliminate the necessity of arbitrarily choosing a specific variable to represent an economic concept. Third, we use regional data set of complete 34 provinces in Indonesia. ${ }^{2}$

In the first part of this paper, we quantitatively measure the asymmetric effects of common monetary policy shock in Indonesia on regional inflation. Based on estimates of province-level structural FAVAR, in the second part, we analyze the reasons for differential responses to monetary policy. More specifically, we investigate the role of regional structural characteristics in affecting regional inflation responses to monetary policy. The rest of this paper is organized as follows. The second section presents the methods and data. In Section 3, we discuss previous related literature and how regional structural characteristics may give rise to regional asymmetries in monetary transmission. Section 4 briefly reviews regional structural characteristics and inflation of Indonesian provinces. Section 5 presents the results and discussion, and finally, Section 6 concludes the paper.

\section{Methods and data}

As mentioned in Section 1, the final objective of the present study is to evaluate the role of regional structural characteristics towards regional heterogeneity responses to monetary policy shocks. To achieve the goal, we implement a two-step analysis approach, similar to Carlino and DeFina (1998) and Ridhwan et al. (2014). First, we estimate the regional effects of monetary policy using a structural FAVAR model. Second, we examine the role of regional structural characteristics on heterogeneous regional response to monetary policy changes.

Although previous studies carefully handle the importance of feedback effects among the variables using standard VARs, they fail to incorporate complex dynamics of multiple economic variables involved in the monetary transmission mechanism. This condition is well understood as a typical problem of the degree of freedom in the VAR models. ${ }^{3}$ To solve this problem, we apply the FAVAR model that can include plentiful information. Typically, FAVAR models contain dozens or even hundreds of variables, making it possible to estimate monetary policy's effect on a large number of macroeconomic variables. Moreover, in practice, the central banks' monetary policy decision is formulated based on observation of many variables. Thus, to precisely capture the transmission of monetary policy on the real economy, it is very crucial to apply the model that can handle extensive information set in order to make the identification of monetary policy shock to be more reliable (Bernanke et al., 2005; Boivin et al., 2010; Laine, 2019).

\subsection{FAVAR model and structural shock identification}

The original FAVAR model has the following structure. Let $Y_{t}$ be a $M X 1$ vector of observed economic variables, and $F_{t}$ is a $K X 1$ vector of unobserved factors which captures most of the economic information. According to Bernanke et al. (2005), the dynamic relationship of $Y_{t}$ and $F_{t}$ can be expressed in the VAR form, thus referred to as

\footnotetext{
${ }^{2}$ The study of Ridhwan et al. (2014) only uses the data set of 26 provinces.

${ }^{3}$ Bernanke et al. (2005) argue that depending on the number of observations, standard VAR models typically include around six to no more than eight variables; otherwise, the number of parameters to be estimated would rapidly increase with the lags. This limitation often forces VAR modelers to omit important information in the analysis, leading to biased estimates of VAR coefficients. Furthermore, the limited number of variables can lead to discretionary variables selection of variables to represent the economic concepts (Nurliana et al., 2016).
} 
FAVAR:

$$
\left[\begin{array}{l}
F_{t} \\
Y_{t}
\end{array}\right]=\Phi^{*}(L)\left[\begin{array}{l}
F_{t-1} \\
Y_{t-1}
\end{array}\right]+v_{t}, \leftrightarrow \Phi(\mathrm{L})\left[\begin{array}{c}
F_{t} \\
Y_{t}
\end{array}\right]=v_{t}
$$

where $\Phi(\mathrm{L})$ is an order polynomial with the usual restrictions present and error $v_{t}$ term with zero mean and covariance matrix.

Bernanke et al. (2005) assume that the non-observed factors $F_{t}$ and the observable variables $Y_{t}$ can be related to the informational series in $X_{t}$ as expressed in the following equation:

$$
X_{t}=\Lambda^{\mathrm{f}} F_{t}+\Lambda^{\mathrm{y}} Y_{t}+\varepsilon_{t}
$$

where $\Lambda^{\mathrm{f}}$ is $N X K$ loading matrix, and $\Lambda^{\mathrm{y}}$ is $N X K$ matrix of coefficients, $\varepsilon_{t}$ is $N X K$ error vector with a zero mean.

Following Bernanke et al. (2005), our study applies a two-step approach with Principal Component Analysis (PCA). Firstly, we estimate $\widehat{F_{t}^{1}}, \widehat{F_{t}^{2}}, \ldots, \widehat{F_{t}^{n}}$, which are the first principal components obtained from each group of a series that carry the largest eigenvalue in each category, and secondly, we use the estimated factors within the VAR represented in Equation 1 to estimate $\Phi(\mathrm{L})$. Specifically, following the lead of Bernanke and Boivin (2003) and Bagliano and Morana (2009), before conducting PCA, we first group the variables under consideration into two categories that represent two different economic concepts: 1) financial sector and 2) external sector. To remove the bias towards high variances given the different units of measurement of series used in PCA analysis, we standardize all series to make the values of each series in the data have zero-mean and unit variance. Table A1 in the Appendix contains the list of indicators used in the estimations of the factors.

Then we build a structural form of the FAVAR model to retain the economic interpretation of the model. Following Ridhwan et al. (2014), we also define a vector of exogenous variables represented by a factor that contains major global economic information, including industrial production index and price dynamics in the U.S. and China and the international price indices of oil and other commodities.

The corresponding structural model of our FAVAR therefore can be written in the following reduced form:

$$
Y_{t}=A(L) Y_{t}+B(L) Z_{t}+\mu_{t}
$$

where $Y_{t}$ is $N X 1$ of endogenous variables, $Z_{t}$ is a vector of exogenous variables, $A(L)$ and $B(L)$ are polynomial matrices, and $\mu_{t}$ is a vector of reduced-form disturbances.

We further use the above structural FAVAR (SFAVAR) specification to model economic activity in the 34 Indonesian provinces with a set of endogenous variables for province $i$ as follows:

$$
Y_{t}=\left(G D P_{t}^{n a t}, I N F_{t}^{n a t}, P O L_{t}, N E R_{t}, F I N_{t}, G D P_{i t}, I N F_{i t}\right)
$$

where $G D P_{t}^{n a t}$ is the aggregate national output, $I N F_{t}^{n a t}$ is the aggregate inflation, $P O L_{t}$ is an interest rate variable representing monetary policy stance, $N E R_{t}$ is the nominal exchange rate, $F I N_{t}$ is a financial factor, while $G D P_{i t}$ and $I N F_{i t}$ are regional output and inflation in province $i$ respectively.

Finally, as emphasized by Christiano et al. (1999), the structural equation variables' ordering is crucial in defining the identification criterion. Therefore, the restrictions 
are carefully defined by following Bernanke et al. (2005), who propose to assume that "slow-moving" variables at the national level (in our case, the national GDP (GDP) and $(I N F)$ ) do not respond contemporaneously to unanticipated changes in monetary policy, while "fast-moving" variables at national level (in our case $(F I N)$ ) is allowed to respond contemporaneously to policy shocks.

Therefore, we set the identification restrictions according to some economic theories that only restrict contemporaneous structural parameters as follows:

$$
A_{t}^{-1} B=\left[\begin{array}{ccccccc}
1 & 0 & 0 & 0 & 0 & 0 & 0 \\
* & 1 & 0 & 0 & 0 & 0 & 0 \\
* & * & 1 & 0 & 0 & 0 & 0 \\
* & * & * & 1 & 0 & 0 & 0 \\
* & * & * & * & 1 & 0 & 0 \\
* & * & * & * & * & 1 & 0 \\
* & * & * & * & * & * & 1
\end{array}\right]\left[\begin{array}{c}
G D P_{t} \\
I N F_{t} \\
P O L_{t} \\
N E R_{t} \\
F I N_{t} \\
G D P_{i t} \\
I N F_{i t}
\end{array}\right]
$$

where $*$ indicates unrestricted parameters.

\section{$2.2 \quad$ Data}

Following standard literature on monetary policy transmission analysis using FAVAR models, we use various national and regional variables. In total, we exploit 45 macroeconomic variables with a monthly frequency from January 2010 to December 2019. The endogenous variables at the national level include nominal policy rate $(P O L)$, the growth rate of GDP $(G D P)$, CPI inflation (INF), nominal exchange rate expressed in IDR/USD $(N E R)$, and financial factor $(F I N)$, while external factor $(E X T)$ depicts exogenous variable. ${ }^{4}$ Nominal policy rate $(P O L)$ represents the monetary policy stance by the central bank; nominal exchange rate $(N E R)$ and financial factor $(F I N)$ are intermediate variables through which the monetary policy is transmitted to the whole economy; both the growth rate of GDP $(G D P)$ and CPI inflation $(I N F)$ are the final variables affected by the monetary policy changes. For regional level, we include the growth rate of provincial GRP and CPI inflation. ${ }^{5}$ Data for POL, NER, and INF are collected from Bank Indonesia and the Indonesian Central Bureau of Statistics, respectively.

\section{Literature review: Monetary policy transmission and regional structural characteristics}

A voluminous literature has been dealing with the regional transmission of monetary policy. ${ }^{6}$ Most of the studies discuss the topic in advanced countries or regions, mainly in the United States (the U.S.) and European countries. Perhaps the study by Toal (1977) is one of the earliest attempts to bring evidence on asymmetric regional responses to monetary policy, revealing differences in regional responses to monetary policy in the

\footnotetext{
${ }^{4}$ All series are seasonally adjusted, unit root tests are applied, and data transformation is implemented to warrant stationarity.

${ }^{5}$ We converted the GDP/GRP series from quarterly to a monthly frequency. Therefore, the growth rate of GDP/GRP is the percentage change of GDP/GRP at time $t$ from $t$-12 according to the constant price in 2010. The CPI inflation at the province level is computed as the weighted average of CPI inflation at the city level.

${ }^{6}$ Dominguez-Torres and Hierro (2019) provide a rigorous and updated review of a range of empirical literature dealing with regional effects of monetary policy.
} 
U.S. during 1952-1975. Similarly, the examination by Garrison and Chang (1979) shows the pronounced differential regional impact of monetary and fiscal policy in eight regions of the U.S. during the 1969-1979 period. They find regions with large concentrations of durable goods manufacturing appear to have a more substantial impact than agriculture and mining-based regions that show a relatively small impact. Still in the U.S., by using state-level data during 1960-1978, Garrison and Kort (1983) also find that monetary policy actions (together with fiscal policy) shape different regional economic activity changes.

Unlike the earlier studies that use structural reduced-form equations, Carlino and DeFina $(1998,1999)$ apply structural VAR model and find that the U.S. regions can be categorized into two groups: the core regions that respond to monetary policy actions similar to the U.S. average response and the non-core regions that show less sensitive responses. Regarding the sources of the differential state responses, they find that share of manufacturing appears to be an essential factor in explaining why some regions are more responsive to changes in monetary policy shocks. ${ }^{7}$ In Europe, Arnold and Vrugt (2002, 2004) employ a VAR model and reveal sizable differences in the output responses to monetary policy shocks across provinces in the Netherlands and German over the period from 1973 to 1993 and 1970 to 2000, respectively. Furthermore, they find that those differences are associated with regions' economic structure, such as industry mix, firm size, bank size, and openness.

While Indonesia is a small open economy with massive regional diversity, on the other hand, the study on regional impacts of monetary policy in the country is relatively sparse. So far, the only available study that documents regional differences of monetary policy impacts in Indonesia is the one by Ridhwan et al. (2014). They analyze factors that determine the different effects of monetary policies between regions after previously identifying heterogeneous effects of monetary policy across 26 Indonesian provinces by using a VAR model. Like most of the literature, they find two crucial features that significantly affect monetary policy's regional effects: industrial composition (especially the share of manufacturing industry) and firm and bank size. In the Indonesian economy, these imply the signification of interest rate channel and credit channel of monetary policy transmission.

Empirical studies generally find that asymmetrical effects of monetary policy across regions reflect heterogeneous socioeconomic structure. Indeed, the literature brings several explanations on why the impact of monetary policy can vary across regions. Among several plausible explanations, most studies explain the following four critical structural characteristics which constitute asymmetric territorial effects of monetary policy: (i) heterogeneity in the industrial composition that is sensitive to interest rate (interest rate channel), (ii) difference in bank credit (credit channel), (iii) difference in regional exports intensity, and (iv) the degree of labor market rigidities.

\subsection{Industrial composition or industry mix}

The importance of industrial composition across regions accentuates the relevance of the interest rate channel of monetary transmission. If regions have different industry composition, the effect of a change in the policy interest rate would be more significant on the regions where the share of interest-sensitive industries in the economy is relatively

\footnotetext{
${ }^{7}$ They also find weakly significant importance of firms and banks size in influencing regional responses to monetary policy changes.
} 
higher (see, e.g., Taylor, 1995; Mishkin, 1996). This is because some industries are more interest-sensitive than others. While classifying more interest-sensitive industries is an open question, some studies include durable and investment goods producers and other highly capital-intensive industries as interest-sensitive (Carlino and DeFina, 1999).

\subsection{Financial structure: the importance of bank credit}

The credit channel of monetary policy transmission assumes no perfect substitution of retail bank deposits and loans. Most borrowers cannot access financial sources unless they obtain from banks. The credit channel argues that in addition to the traditional interest rate channel, monetary policy works by affecting bank assets, i.e., loans (Bernanke and Blinder, 1992). For example, a loosening monetary policy will raise the collateral price and increase banks' equity capital or net worth, allowing them to access more financial sources. As a result, the amount of bank loans available is raising since bank reserves and deposits increase, and this eventually will affect aggregate demand by accelerating investment and consumption. The responses to monetary policy might differ from one bank to another, depending on the components of credit channel: the bank's balance sheet, bank's lending capacity, and bank's capital. However, the different reaction of all credit channel components across individual banks is reflected in the total amount of bank credit disbursed as a finance source in the economy, either for consumption or investment. Empirical evidence suggests that the credit channels would amplify the effects of monetary policy on output and prices more forcefully if bank credit is more important in an economy, indicated by the higher ratio of total bank credit to Gross Domestic Product (GDP) (see, e.g., Dornbusch et al., 1998; Cecchetti et al., 1999; Mihov, 2001).

\subsection{Difference in regional exports intensity}

The importance of regional export intensity towards monetary policy's differential effect has still been debated given the mixed empirical evidence. On the one hand, some studies argue that regions with more export-intensive industries appear to be more responsive to monetary policy change. When the contractionary policy being implemented, currency appreciation might push export products' prices to rise, reducing domestic firms' competitiveness and dragging down demand for exports. With the same logic, currency appreciation might lead to a surge in imports due to the relatively cheaper price of imported goods and lower size of the mark-up. The combination of these two effects stemming from currency appreciation eventually worsens net exports - decrease in exports and increase in imports - and might push domestic price level downward due to income effect (Hayo and Uhlenbrock, 2000). On the other hand, evidence from different studies supports the view that monetary policy effects are less pronounced in the highly intensive exporting regions (Ber et al., 2001). The central argument of this view is mainly based on the evidence for a supply-side effect that works via domestic credit market under the free movement of international capital. When borrowing from domestic financing becomes more expensive due to monetary tightening, exporting firms can access alternative financing from the foreign currency market - from foreign financial institutions or their affiliated parties - and thus, do not necessarily reduce their investment. Moreover, exporting firms' financial condition is less exposed to domestic interest rates since their revenue largely depends on external market conditions. 


\subsection{The degree of labor market rigidities}

In the context of monetary policy transmission, labor market rigidities express how frequently nominal wages can be adjusted given a circumstance. As suggested by the baseline New Keynesian business cycle model, when nominal wages can be adjusted less frequently, the response of firms' marginal costs to a monetary policy shock is minimal and thus reflected in a weaker inflation response (see, for example Galí, 2015). In practice, a group of empirical studies supports this view with the different model specifications to explain the precise mechanisms (see, e.g., Zanetti, 2007; Christoffel and Kuester, 2008; Lechthaler et al., 2010) . In general, the studies find that inflation responses to a monetary policy shock are more muted in economies with more rigid labor markets.

\section{Regional economic structure and regional inflation in Indonesia}

Indonesia is a spatially diverse nation with hundreds of ethnic groups and cultures, different natural resource endowments, and demographic structure spreading throughout 34 provinces. Known as one of the most heterogeneous countries on earth and the world's largest archipelago, Indonesia has long been facing regional development disparity issues (Resosudarmo and Vidyattama, 2006).

For decades, the disparity in Indonesia's regional development has been in the persistent form of the more prosperous west and the poorer east divide. Albeit recent findings by Hill et al. (2008) indicate more even spatial distribution in economic growth ${ }^{8}$, the west and east economic disparity is still seen in the 2010-2019 period, about one decade after the decentralization policy firstly implemented in 2000. Provinces located in the western area of Indonesia (17 provinces in Sumatra and Java-Bali regions) contribute around 81\% of national GDP (where 7 provinces in the Java-Bali region accounts for around $60 \%$ of national GDP), where 17 provinces in the eastern part only share less than $20 \%$ national GDP (Table 1).

Different underlying factors - such as resource endowments, climate and geographical location - also shape Indonesian provinces' regional economic structure. Economic activity in the Java-Bali region is highly supported by its manufacturing industries. As the home of large manufacturing firms, the region is also equipped with adequate physical capital such as infrastructures and better human capital with high-educated labor forces. On the other hand, economic activity in the rest of the regions is generally dependent on the primary sector, notably agriculture and mining. Also, some of nonJava-Bali provinces are more heavily reliant on international trade activities due to their international comparative advantages in extractive industries and strategic geographical position. For example, the Riau Islands province's export value in the Sumatra region that shares a border with Singapore reaches $82 \%$ of its GDP. Similarly, higher export to GDP ratio is typical for natural resource-rich provinces like South Kalimantan, East Kalimantan, West Papua, Bangka Belitung, and Riau.

Beside highlighting the distinguish characteristics of regional economic structure, it is also of our interest to document regional pattern of inflation and briefly introduce recent initiative to control regional inflation in Indonesia. Interestingly, similar to the spatial distribution of GDP across regions, there is a prolonged unique feature of regional

\footnotetext{
${ }^{8}$ Hill et al. (2008) find that the poorest regions - located mainly in the eastern area - have broadly achieved comparably well as the regions in the western area and the national average, as shown in Table 1 .
} 
inflation in Indonesia, i.e., inflation in the Java-Bali region tends to behave closely to the national inflation. In contrast, inflation in provinces outside the Java-Bali region is more unsynchronized. For example, some provinces in Sumatra, one province in Sulawesi, and one province in the Eastern region recorded inflation twice higher than national inflation in 2016 and 2018, respectively (see Figure 1). It may provide an initial impression about the heterogeneous pattern in regional inflation dynamics and different responses of regional inflation to monetary policy changes.

Controlling inflation in a developing and regionally diversified country like Indonesia is complicated. Some studies find that the source of inflation in Indonesia is not only from the demand-side but also coming from the irregularities in supply-side such as disturbance in production and distribution of food commodities (see, e.g., Alamsyah et al., 2001; Affandi et al., 2011; Tirtosuharto and Adiwilaga, 2013; Purwono et al., 2020). Every province can experience different forms and timing of these supply shocks, adding complication in formulating and implementing inflation controlling measures. Therefore, coordinative policies between the central bank and government (both national and regional) are required to manage regional inflation effectively. One historical milestone of inflation controlling policy in Indonesia, especially at the regional level, is through the establishment of a Regional Inflation Controlling Team (RICT) known as Tim Pengendalian Inflasi Daerah (TPID) in 2008. ${ }^{9}$ Under this coordination, the central bank will implement monetary policy to anchor inflation expectation, while the government's sectoral policies will tackle the distortion in the supply side.

\footnotetext{
${ }^{9}$ The main duties of the team include collecting the price data of selected goods, expanding local capacity in producing foodstuffs, improving the logistic system, and planning and executing regional policy to control regional inflation. The coordinative inflation controlling policy is further strengthened by establishing National Inflation Controlling Team (NICT) or Tim Pengendalian Inflasi Nasional (TPIN) as stated in the 2017 Presidentâs Decree of the Republic of Indonesia No.23.
} 
Table 1: Selected economic and financial variables by provinces

\begin{tabular}{|c|c|c|c|c|c|c|c|c|c|c|c|c|}
\hline \multirow[t]{2}{*}{ Province } & \multirow[t]{2}{*}{ Region } & \multirow{2}{*}{$\begin{array}{l}\text { GDP share } \\
(\%)\end{array}$} & \multirow{2}{*}{$\begin{array}{l}\text { GDP growth } \\
(\%, \text { yoy })\end{array}$} & \multicolumn{4}{|c|}{ GDP by sectors ( $\%$ to GDP) } & \multicolumn{3}{|c|}{ GDP by expenditure (\% to GDP) } & \multirow{2}{*}{$\begin{array}{l}\text { Bank lending } \\
\text { to GDP ratio }\end{array}$} & \multirow{2}{*}{$\begin{array}{l}\text { Unemployment } \\
\text { rate }\end{array}$} \\
\hline & & & & Agriculture & Mining & Manufacturing & Construction & Consumption & Investment & Export & & \\
\hline Aceh & Sumatra & 1.32 & 2.98 & 26.73 & 10.44 & 6.69 & 9.11 & 55.38 & 32.21 & 5.00 & 27.18 & 8.22 \\
\hline North Sumatra & Sumatra & 4.61 & 5.58 & 25.11 & 1.24 & 19.74 & 12.24 & 51.74 & 29.79 & 22.57 & 38.15 & 6.37 \\
\hline Riau & Sumatra & 5.11 & 2.77 & 24.31 & 25.31 & 27.60 & 7.50 & 31.83 & 28.96 & 39.77 & 17.51 & 6.44 \\
\hline West Sumatra & Sumatra & 1.56 & 5.66 & 23.82 & 4.34 & 10.94 & 8.67 & 52.83 & 29.75 & 14.45 & 31.86 & 6.37 \\
\hline Riau Islands & Sumatra & 1.68 & 5.65 & 3.64 & 16.14 & 38.08 & 17.32 & 37.51 & 39.86 & 82.99 & 26.65 & 6.63 \\
\hline Bangka Belitung & Sumatra & 0.51 & 4.75 & 18.19 & 14.41 & 23.50 & 8.09 & 51.37 & 21.76 & 51.37 & 31.44 & 4.16 \\
\hline Jambi & Sumatra & 1.37 & 5.71 & 26.02 & 25.44 & 11.14 & 6.80 & 45.34 & 22.85 & 27.45 & 28.44 & 4.31 \\
\hline Bengkulu & Sumatra & 0.42 & 5.62 & 30.02 & 3.83 & 6.17 & 4.50 & 63.20 & 43.10 & 10.00 & 45.67 & 3.83 \\
\hline South Sumatra & Sumatra & 2.84 & 5.56 & 18.49 & 22.27 & 18.68 & 11.42 & 63.48 & 37.99 & 17.87 & 35.14 & 5.23 \\
\hline Lampung & Sumatra & 2.22 & 5.54 & 31.69 & 6.04 & 17.84 & 9.16 & 59.48 & 31.79 & 19.90 & 27.51 & 4.98 \\
\hline Banten & Java-Bali & 4.08 & 5.99 & 5.70 & 0.78 & 36.90 & 9.00 & 58.34 & 30.44 & 29.21 & 61.70 & 10.03 \\
\hline Jakarta & Java-Bali & 16.16 & 6.16 & 0.10 & 0.21 & 12.95 & 13.29 & 58.65 & 44.86 & 20.61 & 74.35 & 8.32 \\
\hline West Java & Java-Bali & 13.43 & 5.69 & 8.11 & 2.37 & 43.54 & 7.98 & 63.61 & 24.91 & 23.04 & 40.98 & 8.91 \\
\hline Central Java & Java-Bali & 9.00 & 5.31 & 14.25 & 2.11 & 34.74 & 10.22 & 60.62 & 29.16 & 8.61 & 30.85 & 5.37 \\
\hline Yogyakarta & Java-Bali & 0.93 & 5.48 & 9.47 & 0.58 & 13.21 & 9.68 & 59.71 & 27.07 & 4.83 & 34.58 & 3.69 \\
\hline East Java & Java-Bali & 14.56 & 5.83 & 12.02 & 5.20 & 29.43 & 9.16 & 61.04 & 27.54 & 14.91 & 30.58 & 4.26 \\
\hline Bali & Java-Bali & 1.43 & 6.33 & 14.84 & 1.15 & 6.60 & 9.53 & 53.74 & 32.61 & 35.11 & 56.72 & 2.02 \\
\hline West Kalimantan & Kalimantan & 1.25 & 5.32 & 23.56 & 4.59 & 16.62 & 10.54 & 53.97 & 32.29 & 11.91 & 47.12 & 4.31 \\
\hline Central Kalimantan & Kalimantan & 0.87 & 6.61 & 21.92 & 16.39 & 15.10 & 8.54 & 41.21 & 42.68 & 21.04 & 46.98 & 3.86 \\
\hline South Kalimantan & Kalimantan & 1.24 & 5.10 & 14.61 & 27.52 & 13.02 & 7.29 & 46.78 & 22.05 & 78.26 & 44.00 & 4.79 \\
\hline East Kalimantan & Kalimantan & 5.03 & 2.76 & 6.20 & 50.07 & 21.05 & 6.82 & 14.17 & 25.57 & 62.01 & 21.13 & 8.06 \\
\hline North Kalimantan & Kalimantan & 0.54 & 6.61 & 17.36 & 29.69 & 9.66 & 11.82 & 17.56 & 30.77 & 26.49 & 13.30 & 5.21 \\
\hline North Sulawesi & Sulawesi & 0.78 & 6.22 & 21.13 & 4.96 & 10.50 & 12.93 & 47.74 & 37.60 & 15.73 & 45.26 & 7.70 \\
\hline Gorontalo & Sulawesi & 0.24 & 7.00 & 37.33 & 1.35 & 4.03 & 11.73 & 61.25 & 31.81 & 0.63 & 45.01 & 4.39 \\
\hline Central Sulawesi & Sulawesi & 0.89 & 8.93 & 32.38 & 12.58 & 9.12 & 10.94 & 52.97 & 40.82 & 22.55 & 31.98 & 4.09 \\
\hline West Sulawesi & Sulawesi & 0.28 & 7.47 & 40.60 & 2.16 & 10.06 & 7.82 & 53.05 & 28.13 & 8.67 & 27.14 & 2.91 \\
\hline South Sulawesi & Sulawesi & 2.76 & 7.55 & 21.63 & 6.08 & 13.90 & 11.93 & 54.43 & 37.41 & 6.92 & 38.44 & 5.86 \\
\hline Southeast Sulawesi & Sulawesi & 0.80 & 7.68 & 24.42 & 20.82 & 6.23 & 12.28 & 48.74 & 41.21 & 12.07 & 26.26 & 4.05 \\
\hline West NT & Eastern & 0.92 & 3.66 & 22.83 & 19.93 & 4.67 & 9.47 & 64.10 & 30.88 & 12.74 & 36.46 & 4.66 \\
\hline East NT & Eastern & 0.63 & 5.24 & 28.86 & 1.43 & 1.27 & 10.65 & 77.32 & 40.69 & 2.22 & 36.06 & 3.23 \\
\hline Maluku & Eastern & 0.28 & 6.00 & 24.39 & 3.08 & 5.40 & 6.82 & 66.26 & 29.98 & 9.69 & 38.90 & 8.88 \\
\hline North Maluku & Eastern & 0.23 & 6.59 & 23.69 & 11.08 & 6.09 & 6.44 & 59.22 & 30.40 & 22.02 & 58.01 & 5.01 \\
\hline West Papua & Eastern & 0.58 & 4.90 & 10.59 & 22.13 & 31.94 & 10.91 & 26.17 & 18.23 & 55.52 & 22.06 & 6.42 \\
\hline Papua & Eastern & 1.45 & 3.10 & 11.42 & 42.25 & 2.02 & 10.35 & 40.99 & 27.01 & 21.70 & 13.19 & 3.63 \\
\hline
\end{tabular}

Notes: The statistics are the mean of respective variables over the period from 2010-2019.

Sources: Authors' computation. GDP and unemployment data from Indonesian Central Bureau of Statistics, bank lending data from Bank Indonesia. 


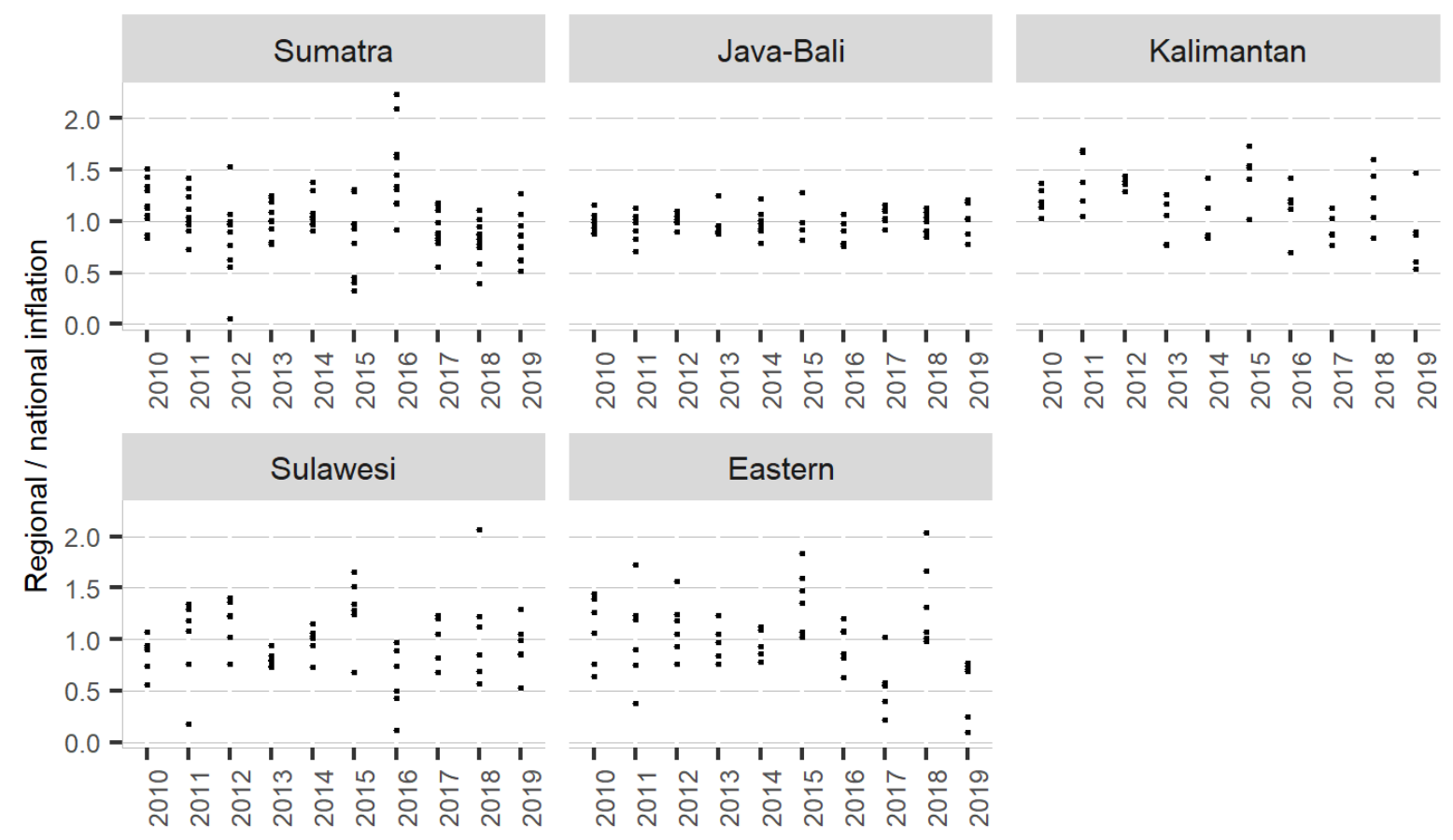

Figure 1: Regional inflation relative to national inflation. Note: Relative value $=1$ means provincial inflation $=$ national inflation at given period.

\section{$5 \quad$ Results and discussion}

\subsection{Heterogeneous effects of a monetary policy shock on regional inflation}

The estimated coefficients and factors in the SFAVAR model are shown in Table A2 in the Appendix. ${ }^{10}$ The coefficients of GDP growth, inflation, and nominal exchange rate are consistent with theory. Both GDP growth and inflation decline following the monetary policy shocks in the previous period, while nominal exchange rate appreciates. We also report the impulse response function in Figure A1 in the Appendix that shows the estimated impulse response for each variable and factor to a one standard deviation positive shock to monetary policy.

The responses are generally of the expected sign and magnitude. Following the increase of the policy rate, the nominal exchange rate appreciates immediately. When the domestic real interest rate of a country rises (drops) as a result of contractionary (expansionary) monetary policy, assets denominated in domestic currency will become more (less) attractive against assets in foreign currency, leading to appreciation (depreciation) of the domestic currency. The increase in policy rate is then followed by the decrease of financial factor as predicted by the financial accelerator and bank lending channel theoretical model. The rise in uncertainty about firms' credit quality makes financial institutions more cautious about lending loans, which then translate into higher interest rates and tighter standards for lending. The increase in the policy rate also decreases financial institutions' liquidity and capital buffers, thus reducing their ability to lend. The ultimate impact is the decline in new loans, and it leads to lower GDP growth.

\footnotetext{
${ }^{10}$ We use lag 1 as indicated by the Schwarz and Hannan-Quinn information criterion.
} 
Although there is a "price puzzle" observed, the response of monetary tightening is finally followed by a drop in inflation pressure from the seventh month onward as the market expects slowing demand. The existence of a "price puzzle" in monetary transmission - that is, the rise in prices in the short term due to positive shocks from the monetary policy contraction - has also been evidenced in other countries, as documented by Ramey (2016). ${ }^{11}$ For the case of Indonesia, Kusmiarso et al. (2002), Harahap et al. (2013), and Nurliana et al. (2016) also show a "price puzzle' in monetary transmission.

After implementing SFAVAR at the national level, we proceed our analysis to the province level as expressed in Equation 4 to capture the contemporaneous response of inflation in each province to a common monetary policy shock. In Figure 2, we plot the impulse response of SFAVAR analysis at both the national and province level. All graphs share the same scale on the vertical axes to facilitate comparability. The figure demonstrates the evidence of heterogeneous effects of a common monetary shock across Indonesian regions, where provinces in Java and Bali islands have a very similar response to national response.

\footnotetext{
${ }^{11}$ Concerning the impact of monetary policy shock on price, the "price puzzle" is not always present. For example, a group of studies finds "price puzzle" (e.g., Christiano et al., 1999; Bernanke et al., 2005) but other researchers do not observe it (e.g., Del Negro et al., 2007). For a detailed discussion on "price puzzle", please refer to Ramey (2016).
} 

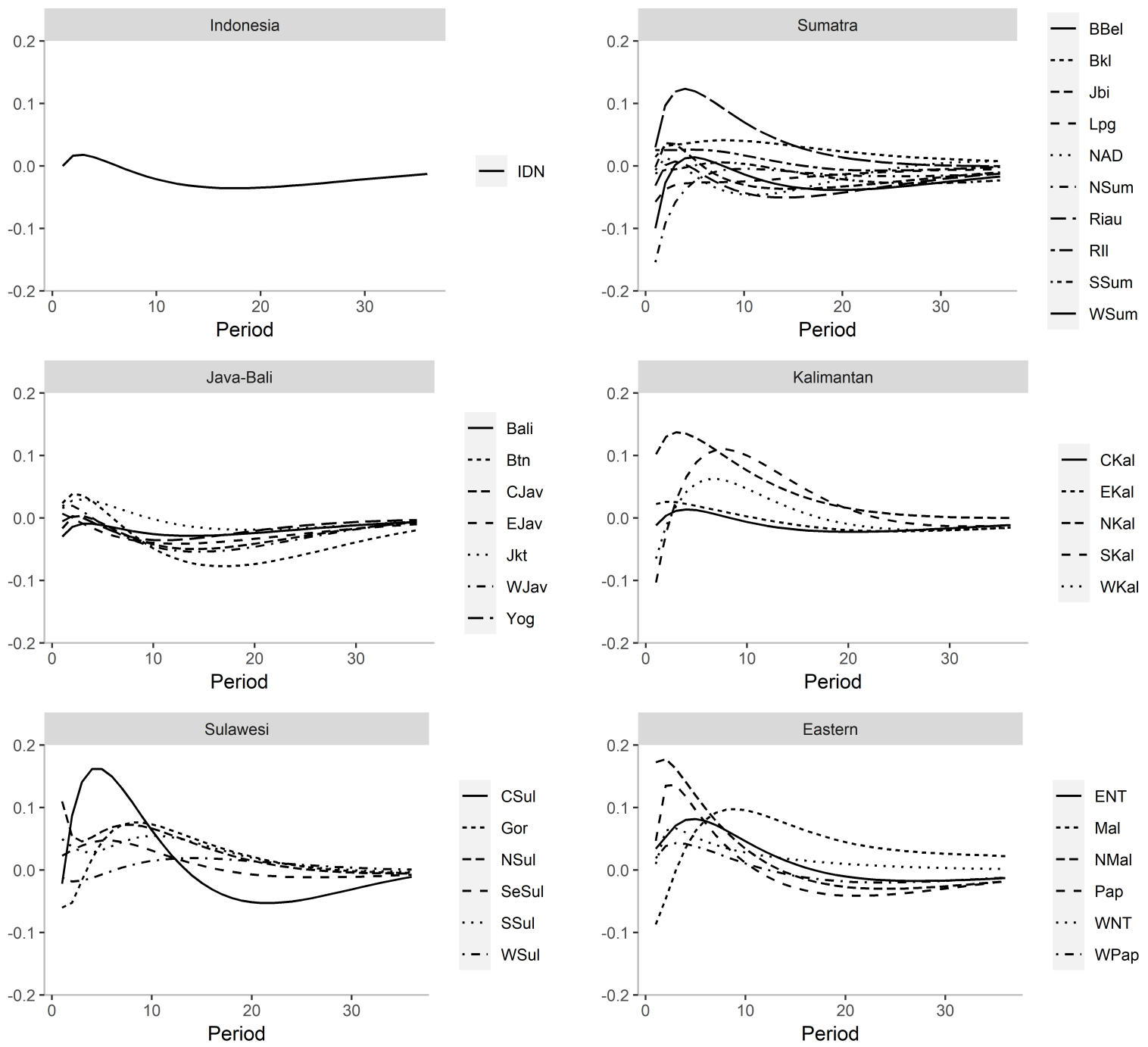

Figure 2: Heterogeneity response of province inflation to a shock on policy rate

Based on the impulse response of each province, we construct the measurement of regional inflation response to monetary policy shocks. We include both the magnitude and length of the impulse response to gauge two measurements of a regional response. The first measure is computed by multiplying the peak of impulse response with the peak's corresponding period. We call this measure as monetary policy impact. The second measure is monetary policy efficiency, where we divide the peak of impulse response with the peak's corresponding period. ${ }^{12}$

We visualize the geographical distribution of the monetary policy impact on regional inflation in Figure 3, where 18 provinces have impacts larger than the cross-sectional mean and 16 provinces exhibit smaller impacts. One appealing pattern stands out. All provinces in Java (except Jakarta) show a larger than average impact. This island is home to large manufacturing industries, where the share of manufacturing sectors in the island reaches nearly $70 \%$ of the national manufacturing industry (based on real GDP in 2019). Furthermore, the size of bank lending in the island contributes $62 \%$ to

\footnotetext{
${ }^{12}$ Note that since we evaluate monetary policy transmission on regional inflation, the peak impulse response is expected to be a negative value. Thus, we multiply the number with -1 to have the positive direction of the measurement; the higher the number, the larger the monetary policy impact or efficiency.
} 
total national bank lending (2019), implying these two regions' significant role in the national banking industry. Similar patterns are also observed in Ridhwan et al. (2014), where manufacturing regions in Java and Sumatra are more sensitive to monetary policy shocks.

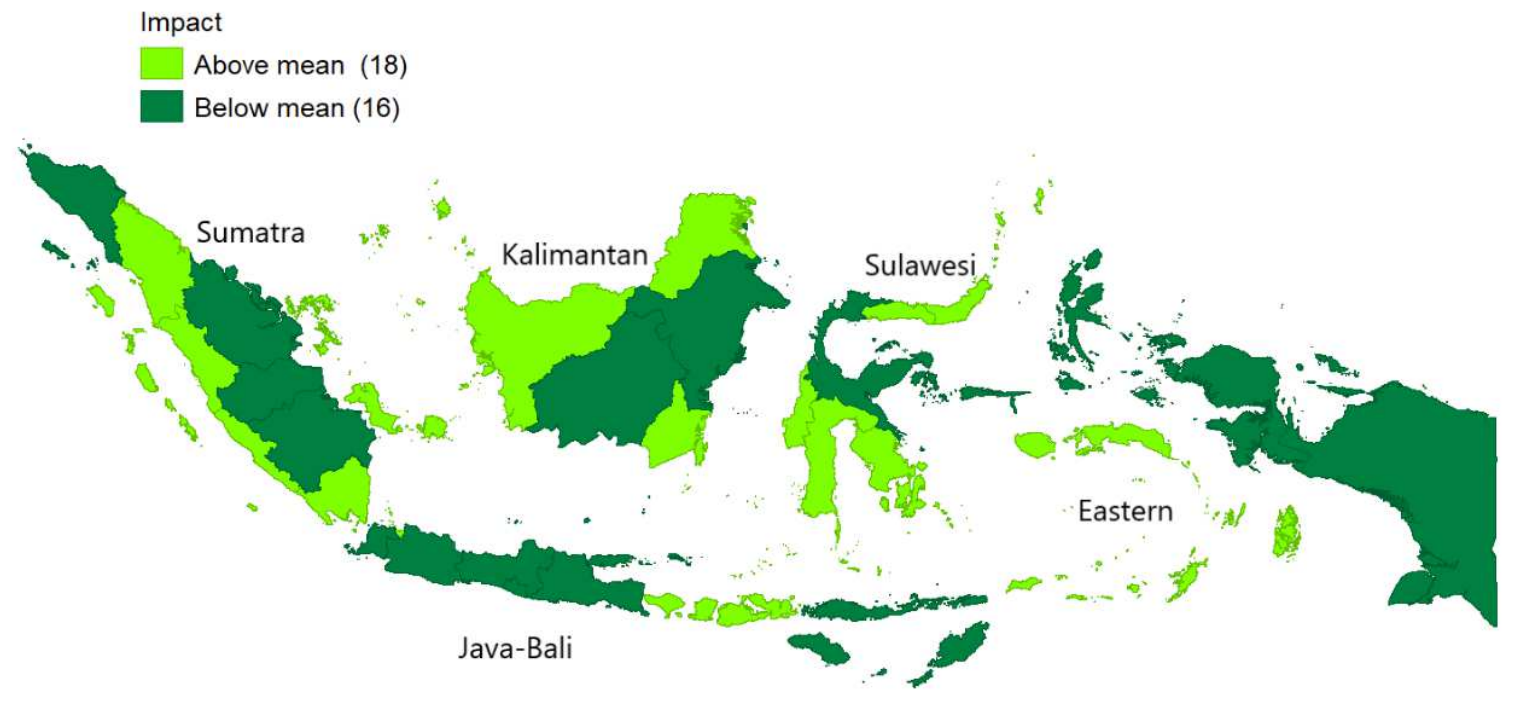

Figure 3: Geographical distribution of the regional inflation impact of a shock on policy rate

\subsection{Regional economic structure and monetary transmission}

At this moment, we have shown our findings from SFAVAR analysis that show differences in regional responses following monetary policy actions. Next, we examine regional factors that explain the variation of regional inflation to monetary policy changes. More specifically, our goal is to answer the following question: to what extent the regional structural features explain the heterogeneity of regional inflation responses to monetary policy shock? To achieve this goal, we implement a cross-section Ordinary Least Square (OLS) estimation as follows:

$$
V=\beta_{0}+\Sigma_{j=1 . . p} \beta_{j} Z_{j}+\varepsilon
$$

where the dependent variable $V$ is the measure of monetary policy impact and monetary policy efficiency, respectively, derived from the estimated impulse responses based on the previous FAVAR model, $\beta_{0}$ is the intercept of the model, $Z_{j}$ corresponds to the $j^{\text {th }}$ explanatory variable of the model $(j=1$ to $p)$ representing the regional economic structure, and $\varepsilon$ is the random error with expectation 0 and variance $\sigma^{2}$.

Existing literature provides good backgrounds for selecting regional features that can explain the different responses to monetary policy actions. For example, Arnold and Vrugt $(2002,2004)$ point out the importance of industrial composition to explain regional transmission of monetary policy in the Netherlands and Germany. For the case of Greek, Anagnostou and Papadamou (2016) find that regions' sensitivity to interest rate shocks is related to regions' characteristics such as the share of particular industries in GDP. Finally, Ridhwan et al. (2014) also mention that industrial composition explains the 
variation in regional impacts of monetary policy changes, corroborating the pertinence of the interest rate channel and credit channel in monetary transmission in Indonesia.

Referring to previous literature and discussion in Section 3, we consider several indicators representing regional economic structure that might explain the regional heterogeneity in the response of regional inflation to the monetary policy shock. The first two variables are the share of manufacturing to GDP and the share of mining sector to GDP. Commonly used in previous studies, these two variables are used to capture regional differences in capital-intensive industries or industrial mix. As mentioned earlier, these variables reflect the way monetary policy is transmitted via the interest rate channel. The third and fourth variables are bank lending to GDP ratio and export share to GDP, respectively. While the earlier reflects the relative importance of bank lending to the provincial economy, the latter demonstrates regional openness. In the past literature, these variables have information on how credit channel and exchange rate channel of monetary policy operate at the regional level. As shown in Table 1, these four initial variables represent different regional economic structure that potentially give rise to the regional response's heterogeneity to monetary policy. We also include the manufacturing industry's annual growth rate to support the importance of manufacturing in the regional economy. Moreover, recent studies have shown the relevance of investigating the spatial dependence of regional inflation (see, e.g., Yesilyurt and Elhorst, 2014; Aginta, 2020b). Thus, to capture the role of spatial externality, we include the measure of spatial lag of inflation, that is, the neighboring provinces' inflation rate. More precisely, we compute the spatial lag of the inflation rate by applying the $k$-nearest neighbors (KNN) weight matrix $(\mathrm{W})$. The neighbors of a province are the four nearest provinces based on euclidean distance. ${ }^{13}$ Finally, to capture labor market flexibility, we use the standard deviation of the regional unemployment rate that reflects the labor market's sensitivity to macroeconomic shocks.

Table 2 shows the results of regression on monetary policy impact. Similar to the findings from previous studies, the results reveal that four variables of regional economic structure are statistically significant in affecting regional inflation response to monetary policy shocks (see model (1)). First, both share of manufacturing to GDP and mining sector's share to GDP has a positive effect on the regional impact of monetary policy. In the literature of monetary policy transmission, this finding supports the view that argues the important role of regional differences in industrial composition in explaining the differential effects of monetary policy. The finding also suggests that the interest rate channel of monetary policy in Indonesia is working reasonably well. Second, we find that bank lending to GDP ratio positively affects monetary policy impact on regional inflation. As discussed earlier in Section 3, this result confirms the relevance of a credit channel in monetary policy transmission in Indonesia. Third, the estimated coefficient of export share to GDP is negative, suggesting that the monetary policy impact is lesser in export-dependent regions. This finding supports the view that monetary policy effects are less pronounced in the highly intensive exporting regions (Ber et al., 2001). Exporting firms' real investment will not necessarily decline following a higher real interest rate from tightening monetary policy. Exporting firms can access foreign currency credit because they are usually part of a larger affiliation and are thus more likely to have contacts and reputation in foreign credit markets. Also, they can obtain trade credit from suppliers or customers abroad. Therefore, when domestic real interest is high, exporting firms may continuously finance their investment by raising foreign currency loans (or foreign

\footnotetext{
${ }^{13}$ We use 4 nearest neighbors weigh matrix as the baseline scenario.
} 
Table 2: Estimated equations evaluating the role of economic structure on cross-province variation in monetary policy impact

\begin{tabular}{|c|c|c|c|c|c|}
\hline \multirow[t]{2}{*}{ Variables } & \multicolumn{5}{|c|}{$\begin{array}{c}\text { Dependent variable: } \\
\text { Cross-province monetary policy impact }\end{array}$} \\
\hline & $(1)$ & $(2)$ & $(3)$ & $(4)$ & $(5)$ \\
\hline $\begin{array}{l}\text { Manufacturing sector } \\
(\% \text { of GDP) }\end{array}$ & $\begin{array}{c}0.022^{* * *} \\
(0.006)\end{array}$ & $\begin{array}{c}0.024^{* * *} \\
(0.006)\end{array}$ & $\begin{array}{c}0.025^{* * *} \\
(0.005)\end{array}$ & $\begin{array}{c}0.024^{* * *} \\
(0.006)\end{array}$ & $\begin{array}{c}0.022^{* * *} \\
(0.005)\end{array}$ \\
\hline $\begin{array}{l}\text { Mining sector } \\
(\% \text { of GDP) }\end{array}$ & $\begin{array}{c}0.021^{* * *} \\
(0.007)\end{array}$ & $\begin{array}{c}0.024^{* * *} \\
(0.007)\end{array}$ & $\begin{array}{c}0.029^{* * *} \\
(0.007)\end{array}$ & $\begin{array}{c}0.028^{* * *} \\
(0.007)\end{array}$ & $\begin{array}{c}0.024^{* * *} \\
(0.006)\end{array}$ \\
\hline Bank lending to GDP ratio & $\begin{array}{l}0.010^{*} \\
(0.005)\end{array}$ & $\begin{array}{c}0.011^{* *} \\
(0.005)\end{array}$ & $\begin{array}{c}0.012^{* *} \\
(0.005)\end{array}$ & $\begin{array}{l}0.010^{*} \\
(0.005)\end{array}$ & $\begin{array}{l}0.011^{* *} \\
(0.005)\end{array}$ \\
\hline $\begin{array}{l}\text { Foreign export share } \\
(\% \text { of GDP) }\end{array}$ & $\begin{array}{c}-0.011^{* *} \\
(0.004)\end{array}$ & $\begin{array}{c}-0.011^{* * *} \\
(0.004)\end{array}$ & $\begin{array}{c}-0.012^{* * *} \\
(0.003)\end{array}$ & $\begin{array}{c}-0.012^{* * *} \\
(0.004)\end{array}$ & $\begin{array}{c}-0.009 * * \\
(0.004)\end{array}$ \\
\hline $\begin{array}{l}\text { Manufacturing growth } \\
(\%, \text { yoy })\end{array}$ & & $\begin{array}{c}0.035 * * \\
(0.015)\end{array}$ & $\begin{array}{l}0.028^{*} \\
(0.014)\end{array}$ & $\begin{array}{c}0.031^{* *} \\
(0.015)\end{array}$ & $\begin{array}{l}0.036^{* *} \\
(0.014)\end{array}$ \\
\hline Inflation of neighbor provinces & & & $\begin{array}{c}-0.422^{* *} \\
(0.189)\end{array}$ & $\begin{array}{l}-0.382^{*} \\
(0.200)\end{array}$ & \\
\hline Std.dev. of unemployment rate & & & & $\begin{array}{c}0.102 \\
(0.148)\end{array}$ & \\
\hline Inflation & & & & & $\begin{array}{r}-0.180^{*} \\
(0.096)\end{array}$ \\
\hline Constant & $\begin{array}{l}-0.350 \\
(0.263)\end{array}$ & $\begin{array}{c}-0.618^{* *} \\
(0.268)\end{array}$ & $\begin{array}{c}1.381 \\
(0.930)\end{array}$ & $\begin{array}{c}1.164 \\
(0.991)\end{array}$ & $\begin{array}{c}0.239 \\
(0.526)\end{array}$ \\
\hline Observations & 34 & 34 & 34 & 34 & 34 \\
\hline R-squared & 0.352 & 0.462 & 0.546 & 0.554 & 0.523 \\
\hline
\end{tabular}

Notes: Robust standard errors in parentheses. ${ }^{*},{ }^{*},{ }^{* * *}$ indicate significant at the $10 \%$ level, $5 \%$ level, and $1 \%$ level respectively. Source: Authors' calculation.

currency-denominated credit). Because of this reason, exporting firms' income might not be negatively affected by the tight monetary policy. This stable income of exporting firms leads to more persistent aggregate demand in regions that are more export intensive. As a results, the impact of monetary policy on inflation is lesser in intensive exporting regions.

In model (2), (3), and (4) we include more variables to show the robustness of the four variables of regional economic structure. All models show the consistency of the estimates of the four variables, both in sign and magnitude, suggesting their robustness. Moreover, the improved R-squared to around 55\% in model (3) and (4) reflects the importance of our additional variables in explaining the sources of regional heterogeneity in monetary policy impacts. For instance, we find that manufacturing growth has a positive effect on monetary policy's impact, re-emphasizing the role of interest-sensitive industries mentioned before. Also, we find the importance of geographical externality, a new evidence that has never been examined in previous studies. Consistent with our expectation, we find a significant negative effect of inflation in neighboring provinces on 
monetary policy impact; that is, monetary policy impact on inflation is timid in the regions that are geographically close to higher inflation provinces. This particular finding supports the evidence of the presence of spatial dependence in regional inflation dynamics in Indonesia. To verify this evidence, we also estimate the model by changing the spatial lag variable with each province's inflation rate. As shown by model (5), the coefficient of inflation is also negative and statistically significant. ${ }^{14}$.

Finally, we find that the regional impact of monetary policy is not significantly influenced by the labor market condition, even though the coefficient shows the expected sign. We have at least two following suspicious reasons for this finding; first, the measurement of labor market flexibility using the standard deviation of unemployment is far from perfect and second, if the measurement is acceptable, the regional labor market condition in Indonesia is not largely different as opposed to cross-country comparison used in the previous study. In summary, our findings favor mainstream literature that emphasizes the role of regional economic structure on heterogeneity in regional responses to monetary shocks.

In the second regression, we run another cross-provincial regression with efficiency of monetary policy as a dependent variable. We separate efficiency of monetary policy from total impact of monetary policy in considering diverse consequence of monetary policy observed from Figure 2. The figure shows that it takes almost 36 months for the impulse response to dies out in some provinces while it takes only 12 to 15 months in some other provinces. It also shows that the impulse response quickly hits the maximum and dies out faster in some provinces while it slowly hits the maximum and dies out more gradually in some other provinces. Diversity of the shape of the impulse response function indicates that the determinants of the speed or efficiency of monetary policy transmission could be different from its total impact. For this reason, efficiency of monetary policy is defined as maximum values of the impulse response divided by the months it takes for the impulse response to hit the maximum.

The regression outcome is shown in Table 3. The R-squared, $61.3 \%$ for model (1) and around $60 \%$ for others are fairly good since this is a cross-section regression. We examine six variables combined with some other variables to show robustness of these six variables. The outcome shows different determinants from the regression outcomes for total impact of monetary policy discussed before. Firstly, foreign import - the share of foreign import divided by provincial GDP - is significant with positive sign. Monetary policy affects exchange rate and therefore prices of imported goods. Monetary policy seems to have a quick effect on inflation in those provinces where imported goods account for a large share in consumption. This finding suggests that exchange rate channel is effective in monetary transmission of Indonesia.

\footnotetext{
${ }^{14}$ The negative sign of inflation coefficient can be explained from the notion of inflation inertia (Fuhrer and Moore, 1995; Mankiw, 2001). Inertia in the inflationary process means that it takes a longer time to bring the inflation down to the target if the output costs, such as wage, are not easily adjusted due to high inflation in the past. Therefore, if inflation is inertia, it is natural to expect that monetary policy impact on inflation is smaller when the inflation rate is high. Wimanda et al. (2011) find significant inertia when analyzing Indonesia's inflation using a hybrid version of the New Keynesian Phillips Curve (NKPC)
} 
Table 3: Estimated equations evaluating the role of economic structure on cross-province variation in monetary policy efficiency

\begin{tabular}{|c|c|c|c|c|}
\hline \multirow[t]{2}{*}{ Variables } & \multicolumn{4}{|c|}{$\begin{array}{c}\text { Dependent variable: } \\
\text { Cross-province monetary policy efficiency }\end{array}$} \\
\hline & $(1)$ & $(2)$ & $(3)$ & $(4)$ \\
\hline $\begin{array}{l}\text { Manufacturing sector } \\
(\% \text { of GDP) }\end{array}$ & $\begin{array}{c}-0.002^{* *} \\
(0.001)\end{array}$ & $\begin{array}{c}-0.001^{*} \\
(0.001)\end{array}$ & $\begin{array}{l}-0.002^{*} \\
(0.001)\end{array}$ & $\begin{array}{c}-0.002^{* *} \\
(0.001)\end{array}$ \\
\hline $\begin{array}{l}\text { Construction sector share } \\
(\% \text { of GDP })\end{array}$ & $\begin{array}{c}0.005^{* *} \\
(0.002)\end{array}$ & $\begin{array}{l}0.005^{*} \\
(0.003)\end{array}$ & $\begin{array}{c}0.005^{* *} \\
(0.003)\end{array}$ & $\begin{array}{c}0.005^{* *} \\
(0.003)\end{array}$ \\
\hline $\begin{array}{l}\text { Domestic export share } \\
(\% \text { of GDP) }\end{array}$ & $\begin{array}{l}-0.001^{* * *} \\
(0.000)\end{array}$ & $\begin{array}{c}-0.001^{* * *} \\
(0.000)\end{array}$ & $\begin{array}{c}-0.001^{* * *} \\
(0.000)\end{array}$ & $\begin{array}{c}-0.001^{* * *} \\
(0.000)\end{array}$ \\
\hline $\begin{array}{l}\text { Investment share } \\
(\% \text { of GDP) }\end{array}$ & $\begin{array}{c}-0.004^{* * *} \\
(0.001)\end{array}$ & $\begin{array}{c}-0.004^{* * *} \\
(0.001)\end{array}$ & $\begin{array}{c}-0.005^{* * *} \\
(0.001)\end{array}$ & $\begin{array}{c}-0.005^{* * *} \\
(0.001)\end{array}$ \\
\hline $\begin{array}{l}\text { Foreign import share } \\
(\% \text { of GDP) }\end{array}$ & $\begin{array}{c}0.001^{* *} \\
(0.000)\end{array}$ & $\begin{array}{c}0.001^{* *} \\
(0.000)\end{array}$ & $\begin{array}{c}0.001^{* *} \\
(0.000)\end{array}$ & $\begin{array}{c}0.001^{* *} \\
(0.000)\end{array}$ \\
\hline $\begin{array}{l}\text { Changes in housing price } \\
(\%)\end{array}$ & $\begin{array}{c}0.028^{* * *} \\
(0.009)\end{array}$ & $\begin{array}{c}0.025^{* *} \\
(0.010)\end{array}$ & $\begin{array}{c}0.027^{* *} \\
(0.010)\end{array}$ & $\begin{array}{c}0.024^{* *} \\
(0.010)\end{array}$ \\
\hline Std. dev. of GDP growth rates & $\begin{array}{c}-0.006^{* * *} \\
(0.002)\end{array}$ & $\begin{array}{c}-0.007^{* * *} \\
(0.002)\end{array}$ & $\begin{array}{c}-0.006^{* * *} \\
(0.003)\end{array}$ & $\begin{array}{c}-0.007 * * * \\
(0.002)\end{array}$ \\
\hline GDP per capita & $\begin{array}{l}-0.001 \\
(0.001)\end{array}$ & & & \\
\hline $\log (\mathrm{GDP})$ & & $\begin{array}{l}-0.005 \\
(0.006)\end{array}$ & & \\
\hline $\begin{array}{l}\text { Mining sector share } \\
(\% \text { of GDP })\end{array}$ & & & $\begin{array}{r}-4 . \mathrm{E}-04 \\
(0.001)\end{array}$ & \\
\hline $\begin{array}{l}\text { Service sector share } \\
(\% \text { of GDP })\end{array}$ & & & & $\begin{array}{l}-0.001 \\
(0.001)\end{array}$ \\
\hline Constant & $\begin{array}{c}0.043 \\
(0.065)\end{array}$ & $\begin{array}{c}0.100 \\
(0.091)\end{array}$ & $\begin{array}{c}0.048 \\
(0.067)\end{array}$ & $\begin{array}{c}0.080 \\
(0.080)\end{array}$ \\
\hline Observations & 34 & 34 & 34 & 34 \\
\hline R-squared & 0.613 & 0.592 & 0.589 & 0.588 \\
\hline
\end{tabular}

Notes: Robust standard errors in parentheses. $*, * *, * * *$ indicate significant at the $10 \%$ level, $5 \%$ level, and $1 \%$ level respectively. Source: Authors' calculation.

Secondly, on the other hand, the shares of investment to GDP and share of manufacturing sector to GDP, which are bank-credit sensitive variables, are statistically significant but negative with respect to monetary policy efficiency, while the share of manufacturing sector to GDP is statistically significant and positive in Table 2. Possible reason for a negative sign is that disbursements from bank loans are slow. It takes time for manufacturers and companies whose plan to make investment to get approval from banks for a loan because they have to go through negotiation of loan contracts and loan assess- 
ment. Therefore, the impact of monetary policy is slow in those provinces which have high share of bank-credit sensitive manufacturing or investment, while the overall impact of monetary policy is considerable higher when the manufacturing sector accounts for a large share in the provincial economy. The same explanation can be applied to the share of investment to GDP since bank loan is the main borrowing instrument for companies in Indonesia.

The third finding is that provincial housing prices are statistically significant and positive. This finding does not indicate causality but shows positive association between efficiency of monetary policy and housing prices. Theory does not imply causality from monetary policy efficiency to housing price but the other way around, i.e., monetary policy has a quick effect in provinces where housing price is rising since housing sector is heavily credit intensive and its disbursement is quick. This explanation is also true for the statistically significant and positive sign of the construction industry share to GDP.

Apart from those findings above, the regression outcome also shows that monetary policy is very slow when GDP growth fluctuates and share of domestic export to GDP is high, both indicated by a statistically significant negative sign. Monetary policy may not have a quick impact in those provinces where the economy experiences large fluctuation and therefore has a high degree of uncertainty. However, it is hard to find possible reason for statistically significant and negative sign for domestic export share to GDP. One of the possible reasons is that bank credits are not subjective to those companies which are expanding exports because an increase in domestic export sales reduces risk premium of the companies and improve credit-worthiness.

\section{Conclusion}

Evidence shows that, more often than not, regions within a country respond differently to aggregate macroeconomic shocks such as monetary policy changes. This paper analyses the link between a regional structure with the heterogeneous regional response of monetary policy in Indonesia, the largest developing economy in the Southeast Asia region with marked cross-regional economic disparities. By employing the SFAVAR modeling approach proposed by Bernanke et al. (2005), which combines standard VAR with factor analysis, we quantitatively demonstrate the heterogeneous regional responses to monetary policy across 34 provinces of Indonesia by using monthly data from 2010:1 to 2019:12. Spatially, we find that most of provinces in the Java-Bali regions have similar responses to the national responses. This pattern is very similar to the characteristics of regional inflation in Indonesia, where the inflation rates of provinces in the Java-Bali region tend to behave closer to the national inflation. Monetary policy impact in the Java-Bali region is also higher than the cross-regional average impact, owing to the significant dependency on manufacturing and banking activities in its economy.

This paper further investigates the source of those heterogeneous regional responses by focusing on regional structural characteristics. To facilitate the analysis, two measurements of regional inflation response to monetary policy shocks have been formulated based on each province's impulse response. The first measure is called monetary policy impact, computed by multiplying the peak of impulse response with the peak's corresponding period. The second measure is monetary policy efficiency, where we divide the peak of impulse response with the corresponding period of the peak.

In relation to monetary policy impact, our findings support the commonly agreed conclusion that cross-regional differential responses to monetary policy actions can be 
primarily explained by the regions' economic structure. More specifically, we find that the impact of monetary policy is positively affected by the share of manufacturing and mining industries in GDP as well as bank lending to GDP ratio. On the other hand, monetary policy impact is more deemed in provinces with higher export to GDP ratio. We also find other significant sources of heterogeneity; the growth rate of the manufacturing industry and spatial lag of inflation. While the earlier variable supports the importance of manufacturing industries, the latter stimulates new discussion on the relevance of spatial externality of inflation across Indonesian provinces and thus triggers an avenue for further studies.

Regarding to monetary policy efficiency, we find that the monetary policy transmission on regional inflation is more efficient when the share of foreign import to GDP is high, implying the functioning of exchange rate channel. We also find positive association between monetary policy efficiency and housing prices and share of construction to GDP, while monetary policy is less efficient in economy with high economic fluctuation or uncertainty and larger share of domestic export to GDP. Interestingly, we find that the shares of investment to GDP and share of manufacturing sector to GDP, which are bankcredit sensitive variables, are statistically significant with negative signs, as opposed to positive signs when considering monetary policy impact. These different results between monetary policy impact and monetary policy efficiency imply important implications in evaluating monetary policy transmission at the regional level. The effect of monetary policy tends to materialize gradually with a longer time horizon in regions that have a higher share of interest-sensitive industries (manufacturing and mining industries) in their economy and a higher bank loan to GDP ratio, while the monetary policy effect is relatively fast and short-lived in regions that more engage in foreign import activities. To sum up, in relation to previous studies on monetary policy transmission in Indonesia, our findings corroborate the operation of interest rate, bank lending and exchange rate channels of monetary policy on regional inflation. 


\section{Declarations}

\section{Availability of data and materials}

Data and materials used in this study are available are stored in digital repositories https: //figshare.com/s/6d9b852fec754c7796ba.

\section{Competing interests}

No potential conflict of interest was reported by the authors.

\section{Funding}

The authors declare that they received no specific funding for this work.

\section{Authors' contributions}

- Harry Aginta: Collected data, developed theoretical framework, designed and performed computation, analysed data, interpreted the results, and wrote the manuscript.

- Masakazu Someya: Supervised the research, performed computation, interpreted the results, and co-wrote the manuscript.

All authors discussed the results and commented on the manuscript.

\section{Acknowledgements}

The authors would like to appreciate all participants of the 5th International Conference on Economic Structures (ICES 2021) for their constructive comments and suggestions to improve this paper.

\section{Ethics approval and consent to participate}

Not applicable.

\section{Consent for publication}

Not applicable. 


\section{References}

Affandi, Y. et al. (2011). Unveiling stubborn inflation in Indonesia. Ekonomi Dan Keuangan Indonesia, 59(1):47.

Aginta, H. (2020a). Does the law of one price hold in 82 Indonesian cities? Evidence from club convergence approach. Economics Bulletin, 40(4):2844-2858.

Aginta, H. (2020b). Spatial dynamics of consumer price in Indonesia: Convergence clubs and conditioning factors. Asia-Pacific Journal of Regional Science, pages 1-25.

Alamsyah, H., Joseph, C., Agung, J., and Zulverdy, D. (2001). Towards implementation of inflation targeting in Indonesia. Bulletin of Indonesian Economic Studies, 37(3):309-324.

Anagnostou, A. and Papadamou, S. (2016). Regional asymmetries in monetary policy transmission: The case of the Greek regions. Environment and Planning C: Government and Policy, 34(5):795-815.

Arnold, I. J. and Vrugt, E. B. (2002). Regional effects of monetary policy in the Netherlands. International Journal of Business and Economics, 1(2):123.

Arnold, I. J. and Vrugt, E. B. (2004). Firm size, industry mix and the regional transmission of monetary policy in Germany. German Economic Review, 5(1):35-59.

Bagliano, F. C. and Morana, C. (2009). International macroeconomic dynamics: A factor vector autoregressive approach. Economic Modelling, 26(2):432-444.

Ber, H., Blass, A., Yosha, O., et al. (2001). Monetary transmission in an open economy: The differential impact on exporting and non-exporting firms. Bank of Israel, Research Department.

Bernanke, B. S. and Blinder, A. S. (1992). The federal funds rate and the channels of monetary transmission. American Economic Review, 82(4):901-21.

Bernanke, B. S. and Boivin, J. (2003). Monetary policy in a data-rich environment. Journal of Monetary Economics, 50(3):525-546.

Bernanke, B. S., Boivin, J., and Eliasz, P. (2005). Measuring the effects of monetary policy: a factor-augmented vector autoregressive (favar) approach. The Quarterly journal of economics, 120(1):387-422.

Boivin, J., Kiley, M. T., and Mishkin, F. S. (2010). How has the monetary transmission mechanism evolved over time? In Handbook of monetary economics, volume 3, pages 369-422. Elsevier.

Carlino, G. and DeFina, R. (1998). The differential regional effects of monetary policy. Review of Economics and Statistics, 80(4):572-587.

Carlino, G. and DeFina, R. (1999). The differential regional effects of monetary policy: Evidence from the US states. Journal of Regional Science, 39(2):339-358.

Cecchetti, S. G. et al. (1999). Legal structure, financial structure, and the monetary policy transmission mechanism. Economic Policy Review, 5(Jul):9-28.

Cecchetti, S. G., Mark, N. C., and Sonora, R. J. (2002). Price index convergence among United States cities. International Economic Review, 43(4):1081-1099. 
Christiano, L. J., Eichenbaum, M., and Evans, C. L. (1999). Monetary policy shocks: What have we learned and to what end? Handbook of macroeconomics, 1:65-148.

Christoffel, K. and Kuester, K. (2008). Resuscitating the wage channel in models with unemployment fluctuations. Journal of Monetary Economics, 55(5):865-887.

De Grauwe, P. (2000). Monetary policies in the presence of asymmetries. JCMS: Journal of Common Market Studies, 38(4):593-612.

Del Negro, M., Schorfheide, F., Smets, F., and Wouters, R. (2007). On the fit of New Keynesian models. Journal of Business \& Economic Statistics, 25(2):123-143.

Dominguez-Torres, H. and Hierro, L. A. (2019). The regional effects of monetary policy: A survey of the empirical literature. Journal of Economic Surveys, 33(2):604-638.

Dornbusch, R., Favero, C., and Giavazzi, F. (1998). Immediate challenges for the European central bank. Economic Policy, 13(26):16-64.

Fuhrer, J. and Moore, G. (1995). Inflation persistence. The Quarterly Journal of Economics, 110(1):127-159.

Galí, J. (2015). Monetary policy, inflation, and the business cycle: An introduction to the new keynesian framework and its applications second edition. Technical report, Princeton University Press.

Garrison, C. B. and Chang, H. S. (1979). The effect of monetary and fiscal policies on regional business cycles. International Regional Science Review, 4(2):167-180.

Garrison, C. B. and Kort, J. R. (1983). Regional impact of monetary and fiscal policy: a comment. Journal of Regional Science, 23(2):249-261.

Gros, D. and Hefeker, C. (2002). One size must fit all: national divergences in a monetary union. German Economic Review, 3(3):247-262.

Harahap, B. A., Maryaningsih, N., Linda Nurliana, P., and Satyanugroho, R. (2013). Revisiting transmisi suku bunga kebijakan moneter: Pendekatan favar. Technical report, Bank Indonesia Working Paper.

Hayo, B. and Uhlenbrock, B. (2000). Industry effects of monetary policy in germany. In Regional aspects of monetary policy in Europe, pages 127-158. Springer.

Hill, H., Resosudarmo, B. P., and Vidyattama*, Y. (2008). Indonesia's changing economic geography. Bulletin of Indonesian Economic Studies, 44(3):407-435.

Jangam, B. P. and Akram, V. (2019). Do prices converge among indonesian cities? an empirical analysis. Buletin Ekonomi Moneter Dan Perbankan, 22(3):239-262.

Kusmiarso, B., Sukawati, E., Pambudi, S., Angkoro, D., Prasmuko, A., and Hafidz, I. S. (2002). Interest rate channel of monetary transmission in indonesia. Transmission Mechanism of Monetary Policy in Indonesia. Strategic Research Program of the Directorate of Economic Research and Monetary Policy, Directorate of Economic Research and Monetary Policy, Bank Indonesia.

Laine, O.-M. J. (2019). The effect of the ecbâs conventional monetary policy on the real economy: FAVAR-approach. Empirical Economics, pages 1-26. 
Lechthaler, W., Merkl, C., and Snower, D. J. (2010). Monetary persistence and the labor market: a new perspective. Journal of Economic Dynamics and Control, 34(5):968-983.

Mankiw, N. G. (2001). The inexorable and mysterious tradeoff between inflation and unemployment. The Economic Journal, 111(471):45-61.

Mihov, I. (2001). Monetary policy implementation and transmission in the european monetary union. Economic Policy, 16(33):370-406.

Mishkin, F. S. (1996). The channels of monetary transmission: Lessons for monetary policy. Technical report, National Bureau of Economic Research.

Nurliana, L., Wimanda, R. E., Satyanugraha, R., and Centre, S. (2016). Evaluating monetary transmission mechanism in indonesia using a structural favar approach. Monetary Policy Transmission in the SEACEN Economies, pages 19-56.

Purwono, R., Yasin, M. Z., and Mubin, M. K. (2020). Explaining regional inflation programmes in Indonesia: Does inflation rate converge? Economic Change and Restructuring, pages 1-20.

Ramey, V. A. (2016). Macroeconomic shocks and their propagation. Handbook of Macroeconomics, 2:71-162.

Resosudarmo, B. P. and Vidyattama, Y. (2006). Regional income disparity in Indonesia: A panel data analysis. ASEAN Economic Bulletin, pages 31-44.

Ridhwan, M. M., de Groot, H. L., Rietveld, P., and Nijkamp, P. (2014). The regional impact of monetary policy in Indonesia. Growth and Change, 45(2):240-262.

Taylor, J. B. (1995). The monetary transmission mechanism: An empirical framework. Journal of Economic Perspectives, 9(4):11-26.

Tirtosuharto, D. and Adiwilaga, H. (2013). Decentralization and regional inflation in Indonesia. Buletin Ekonomi Moneter Dan Perbankan, 16(2):137-154.

Toal, W. D. (1977). Regional impacts of monetary and fiscal policies in the postwar period: Some initial tests. Federal Reserve Bank of Atlanta.

Wimanda, R. E., Turner, P. M., and Hall, M. J. (2011). Expectations and the inertia of inflation: The case of Indonesia. Journal of Policy Modeling, 33(3):426-438.

Yesilyurt, F. and Elhorst, J. P. (2014). A regional analysis of inflation dynamics in Turkey. The Annals of Regional Science, 52(1):1-17.

Zanetti, F. (2007). A non-walrasian labor market in a monetary model of the business cycle. Journal of Economic Dynamics and Control, 31(7):2413-2437. 


\section{Appendix}

Table A1: List of variables used in PCA analysis

\begin{tabular}{|c|c|c|c|c|}
\hline \multicolumn{5}{|c|}{ Factor: Financial } \\
\hline No. & Indicator & Definition & Units & Original frequency \\
\hline 1 & $\mathrm{~m} 0$ & Currency outside commercial and rural banks & IDR billion & Monthly \\
\hline 2 & m1 & Narrow money & IDR billion & Monthly \\
\hline 3 & $\mathrm{~m} 2$ & Broad money & IDR billion & Monthly \\
\hline 4 & stock_vol & Transaction volume at Jakarta stock exchange & in million stocks & Monthly \\
\hline 5 & stock_val & Transaction value at Jakarta stock exchange & IDR billion & Monthly \\
\hline 6 & stock_indx & Jakarta stock exchange composite index & & Monthly \\
\hline 7 & LQ45 & Consists of 45 stocks that meet a number of specific criteria & & Monthly \\
\hline 8 & jibor_1d & Jakarta Interbank Offered Rate for overnight & $\%$ & Monthly \\
\hline 9 & jibor_1m & Jakarta Interbank Offered Rate for 1 month & $\%$ & Monthly \\
\hline 10 & jibor_3m & Jakarta Interbank Offered Rate for 3 month & $\%$ & Monthly \\
\hline 11 & int_lend_inv & Bank lending rate IDR for investment purposes & $\%$ & Monthly \\
\hline 12 & int_lend_wc & Bank lending rate IDR for working capital purposes & $\%$ & Monthly \\
\hline 13 & int_lend_cons & Bank lending rate IDR for consumption purposes & $\%$ & Monthly \\
\hline 14 & int_sav_1m & Bank time deposit (saving) rate for 1 month & $\%$ & Monthly \\
\hline 15 & int_sav_3m & Bank time deposit (saving) rate for 3 month & $\%$ & Monthly \\
\hline 16 & int_sav_6m & Bank time deposit (saving) rate for 6 month & $\%$ & Monthly \\
\hline 17 & int_sav_12m & Bank time deposit (saving) rate for 12 month & $\%$ & Monthly \\
\hline 18 & int_sav_24m & Bank time deposit (saving) rate for 24 month & $\%$ & Monthly \\
\hline \multicolumn{5}{|c|}{ Factor: External } \\
\hline No. & Indicator & Definition & Units & Original frequency \\
\hline 1 & crude_oil_avg & Commodity monthly price, average & US\$ / barrel & Monthly \\
\hline 2 & crude_oil_brent & Commodity monthly price, Brent & US\$ / barrel & Monthly \\
\hline 3 & crude_oil_dubai & Commodity monthly price, Dubai & US\$ / barrel & Monthly \\
\hline 4 & crude_oil_wti & Commodity monthly price, WTI & US\$ / barrel & Monthly \\
\hline 5 & wcom_en & Commodity monthly price index, energy & $2010=100$ & Monthly \\
\hline 6 & wcom_nen & Commodity monthly price index, non-energy & $2010=100$ & Monthly \\
\hline 7 & wcom_agri & Commodity monthly price index, agriculture & $2010=100$ & Monthly \\
\hline 8 & wcom_bvrg & Commodity monthly price index, beverage & $2010=100$ & Monthly \\
\hline 9 & wcom_food & Commodity monthly price index, foods & $2010=100$ & Monthly \\
\hline 10 & wcom_oilmeals & Commodity monthly price index, oil and meals & $2010=100$ & Monthly \\
\hline 11 & wcom_grains & Commodity monthly price index, grains & $2010=100$ & Monthly \\
\hline 12 & wcom_othrfood & Commodity monthly price index, other foods & $2010=100$ & Monthly \\
\hline 13 & wcom_rawmat & Commodity monthly price index, raw materials & $2010=100$ & Monthly \\
\hline 14 & wcom_timber & Commodity monthly price index, timber & $2010=100$ & Monthly \\
\hline 15 & wcom_otherrawmat & Commodity monthly price index, raw materials & $2010=100$ & Monthly \\
\hline 16 & wcom_fert & Commodity monthly price index, fertilizer & $2010=100$ & Monthly \\
\hline 17 & wcom_metal & Commodity monthly price index, metal & $2010=100$ & Monthly \\
\hline 18 & wcom_basemetal & Commodity monthly price index, base metal & $2010=100$ & Monthly \\
\hline 19 & prec_metal & Commodity monthly price index, precious metal & $2010=100$ & Monthly \\
\hline 20 & inds_US_sa & US industrial production index, seasonally adjusted & $2012=100$ & Monthly \\
\hline 21 & inds_- $\mathrm{CHN}_{\bar{N}}$ & China industrial production index (total industry excluding construction), not SA & $2000=100$ & Monthly \\
\hline 22 & cpi_Us_sa & US consumer price index, seasonally adjusted & $1982=100$ & Monthly \\
\hline 23 & cpi_CHN & China consumer price index, not seasonally adjusted & $2015=100$ & Monthly \\
\hline 24 & ppi_US & US producer price index, not seasonally adjusted & $1982=100$ & Monthly \\
\hline
\end{tabular}


Teble A2: Contemporaneous coefficients estimated from structural FAVAR model

\begin{tabular}{lccccc}
\hline Variable & GDPg & INF & POL & NER & FIN \\
\hline GDPg(-1) & 0.88 & 0.08 .58 & 0.04 & $-8 \mathrm{E}-04$ & 0.07 \\
& $(0.04)$ & $(12.28)$ & $(3.65)$ & $(0.33)$ & $(28.50)$ \\
INF(-1) & $5 \mathrm{E}-03$ & 0.90 & 0.03 & $2 \mathrm{E}-03$ & 0.37 \\
& $(0.00)$ & $(0.05)$ & $(0.02)$ & $(0.00)$ & $(0.12)$ \\
POL(-1) & $-7 \mathrm{E}-03$ & -0.01 & 0.92 & $-3 \mathrm{E}-03$ & -0.31 \\
& $(0.00)$ & $(0.08)$ & $(0.02)$ & $(0.00)$ & $(0.18)$ \\
NER(-1) & 0.27 & 5.25 & 1.30 & 0.20 & 7.46 \\
& $(0.01)$ & $(3.61)$ & $(1.07)$ & $(0.10)$ & $(8.38)$ \\
FIN(-1) & $-8 \mathrm{E}-03$ & 0.03 & 0.03 & $2 \mathrm{E}-04$ & 0.63 \\
& $(0.00)$ & $(0.03)$ & $(0.01)$ & $(0.00)$ & $(0.07)$ \\
C & 0.62 & 0.05 & 0.10 & 0.01 & -0.21 \\
& $(0.00)$ & $(0.76)$ & $(0.23)$ & $(0.02)$ & $(1.77)$ \\
EXT & $-9 \mathrm{E}-03$ & -0.03 & -0.01 & $-1 \mathrm{E}-03$ & -0.01 \\
& $(0.00)$ & $(0.02)$ & $(0.01)$ & $(0.00)$ & $(0.05)$ \\
\hline R-squared & 0.82 & 0.89 & 0.98 & 0.13 & 0.61 \\
Adj. R-squared & 0.81 & 0.89 & 0.97 & 0.08 & 0.59 \\
\hline
\end{tabular}

Note: Standard errors in (). Source: Authors' calculation.
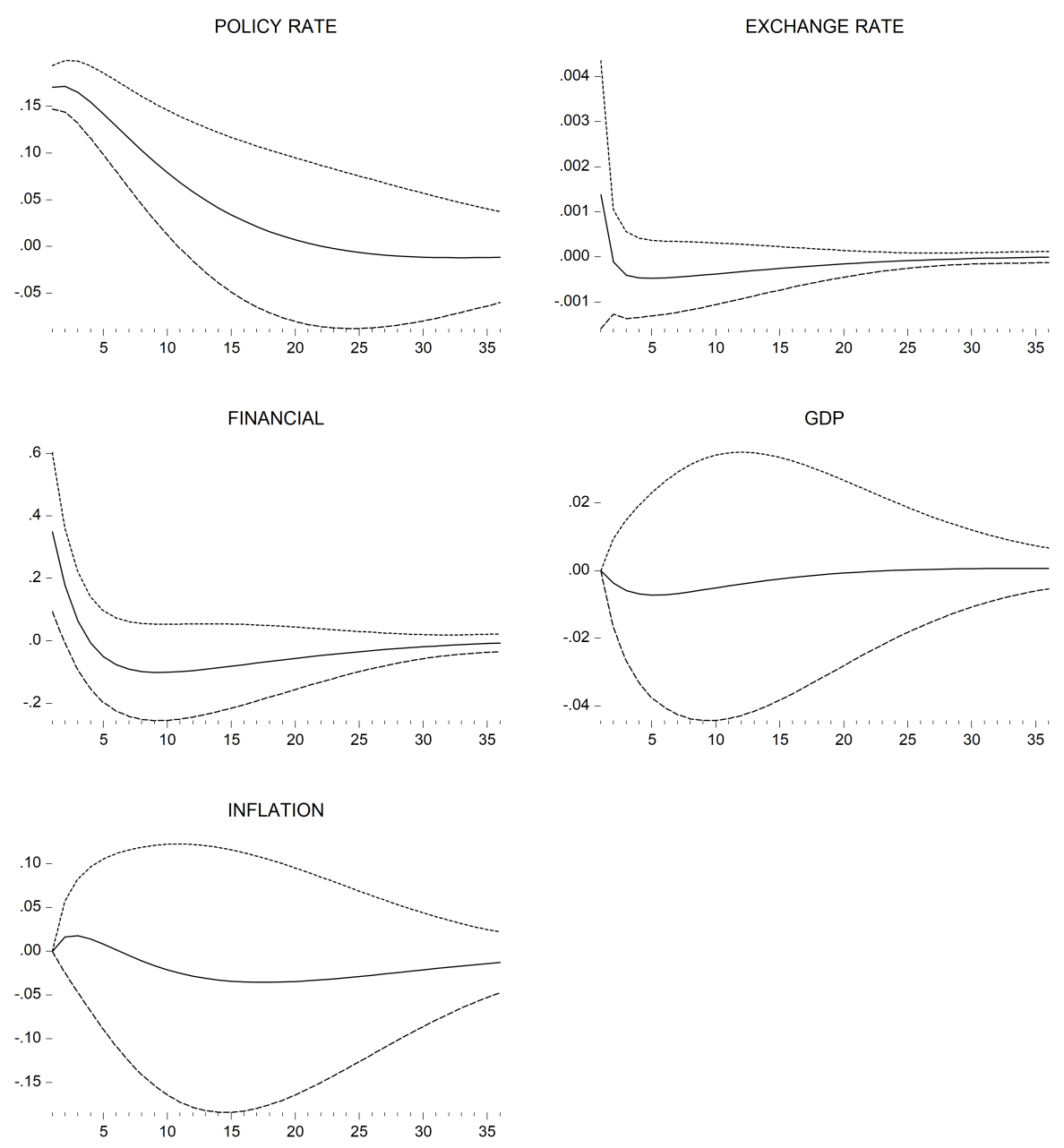

Figure A1: Impulse responses of respective variables to monetary policy shock. Evidence from structural FAVAR. 
Table A3: Abbreviation list

\begin{tabular}{llllll}
\hline Abbreviation & Province & Region & Abbreviation & Province & Region \\
\hline NAD & Aceh & Sumatra & WKal & West Kalimantan & Kalimantan \\
NSum & North Sumatra & Sumatra & SKal & South Kalimantan & Kalimantan \\
Riau & Riau & Sumatra & CKal & Central Kalimantan & Kalimantan \\
WSum & West Sumatra & Sumatra & EKal & East Kalimantan & Kalimantan \\
Ril & Riau Islands & Sumatra & NKal & North Kalimantan & Kalimantan \\
Jbi & Jambi & Sumatra & NSul & North Sulawesi & Sulawesi \\
Bkl & Bengkulu & Sumatra & Gor & Gorontalo & Sulawesi \\
BBel & Bangka Belitung & Sumatra & CSul & Central Sulawesi & Sulawesi \\
SSum & South Sumatra & Sumatra & WSul & West Sulawesi & Sulawesi \\
Lpg & Lampung & Sumatra & SSul & South Sulawesi & Sulawesi \\
Btn & Banten & Java - Bali & SeSul & Southeast Sulawesi & Sulawesi \\
Jkt & Jakarta & Java - Bali & NMal & North Maluku & Eastern \\
WJav & West Java & Java - Bali & Mal & Maluku & Eastern \\
CJav & Central Java & Java - Bali & WNT & West Nusa Tenggara & Eastern \\
Yog & Yogyakarta & Java - Bali & ENT & East Nusa Tenggara & Eastern \\
EJav & East Java & Java - Bali & WPap & West Papua & Eastern \\
Bali & Bali & Java - Bali & Pap & Papua & Eastern \\
\hline
\end{tabular}


Figures

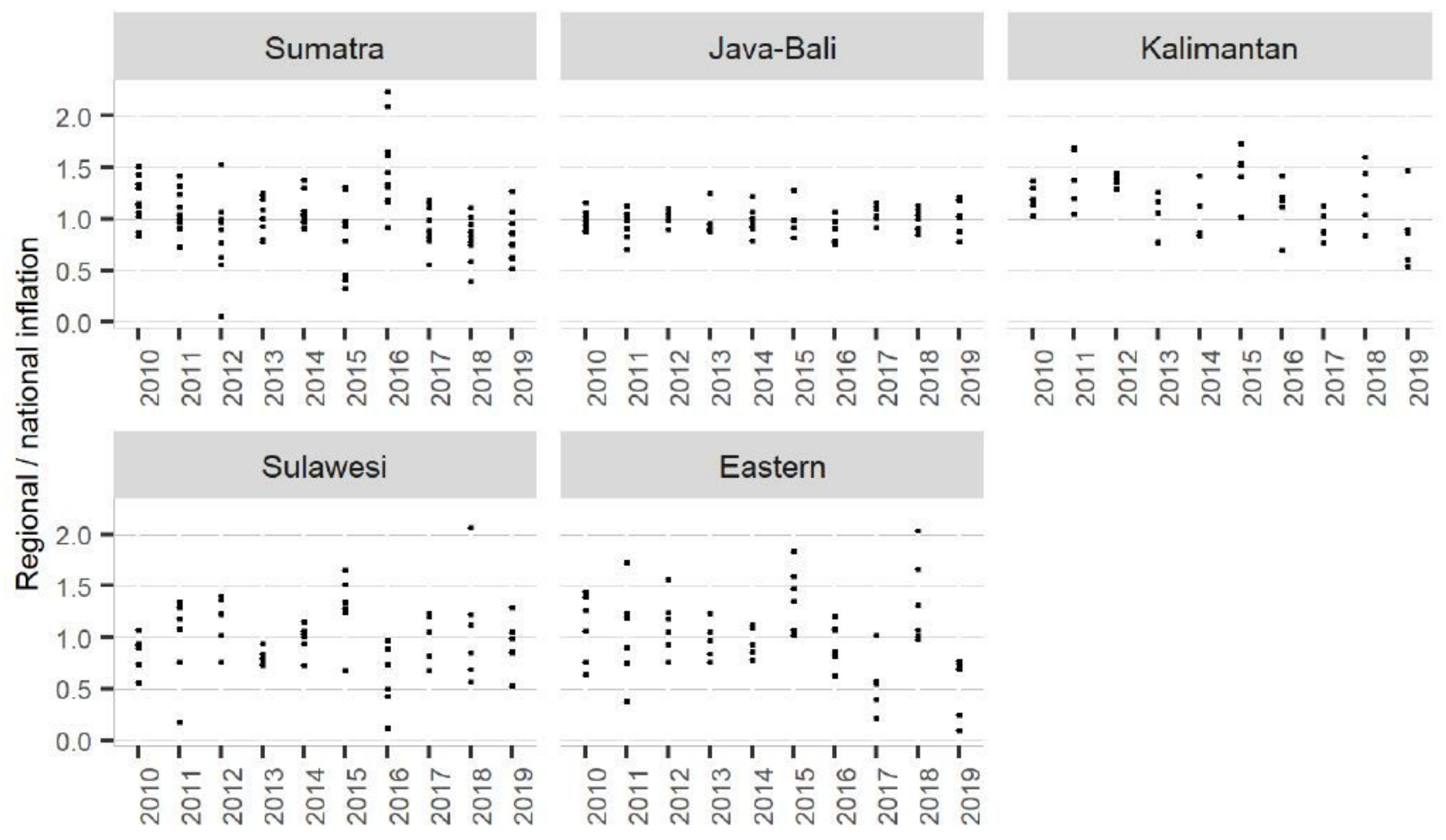

Figure 1

Regional inflation relative to national inflation. Note: Relative value $=1$ means provincial inflation $=$ national inflation at given period. 

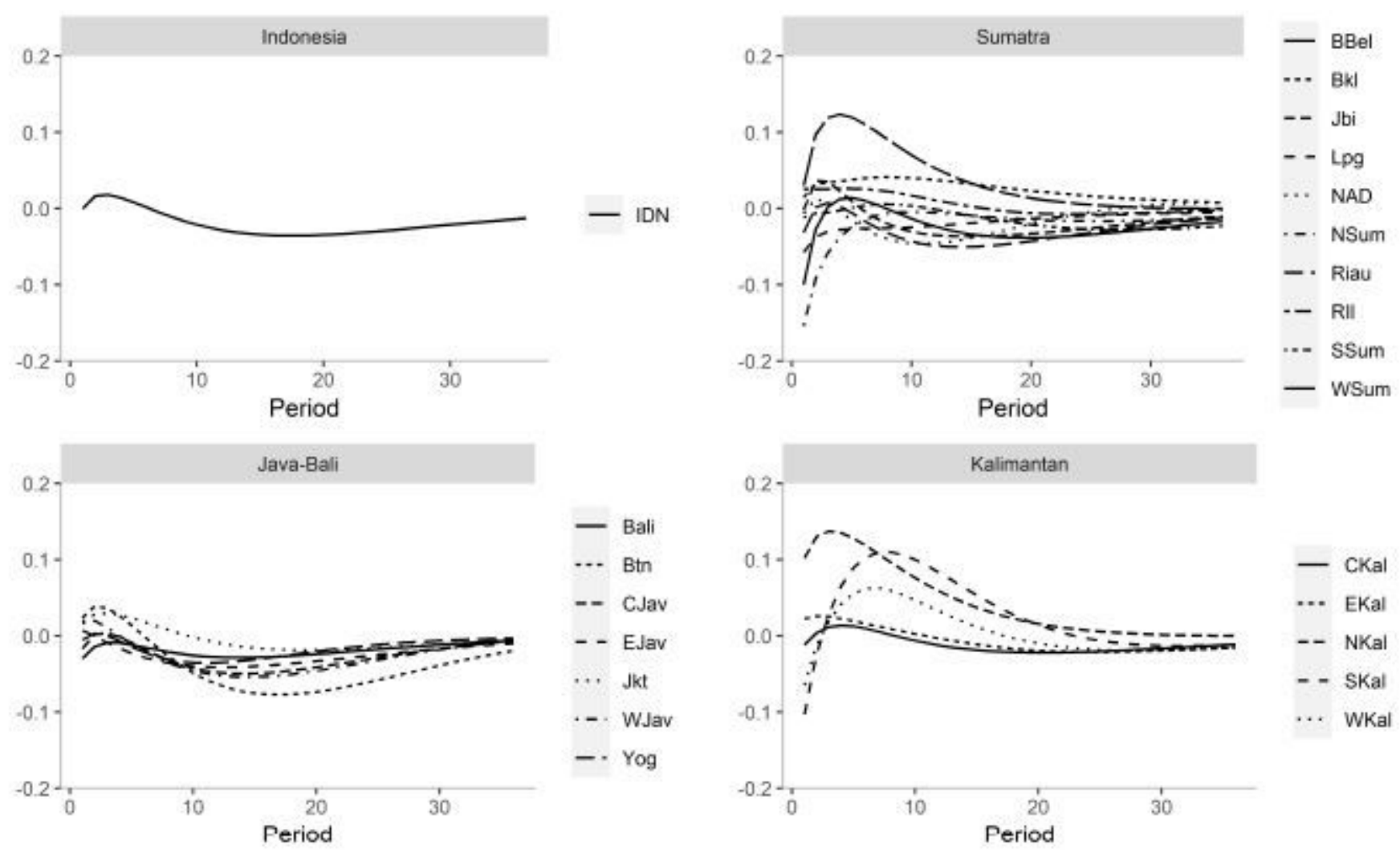

- CKal

... EKal

-- NKal

- SKal

... WKal
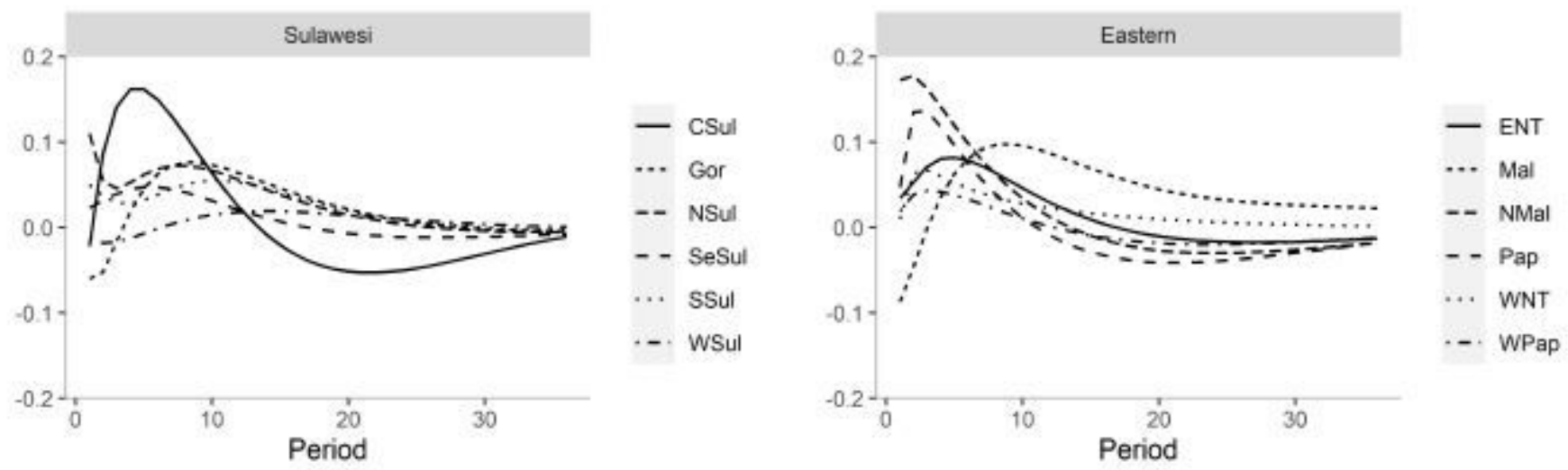

\section{Figure 2}

Heterogeneity response of province inflation to a shock on policy rate 


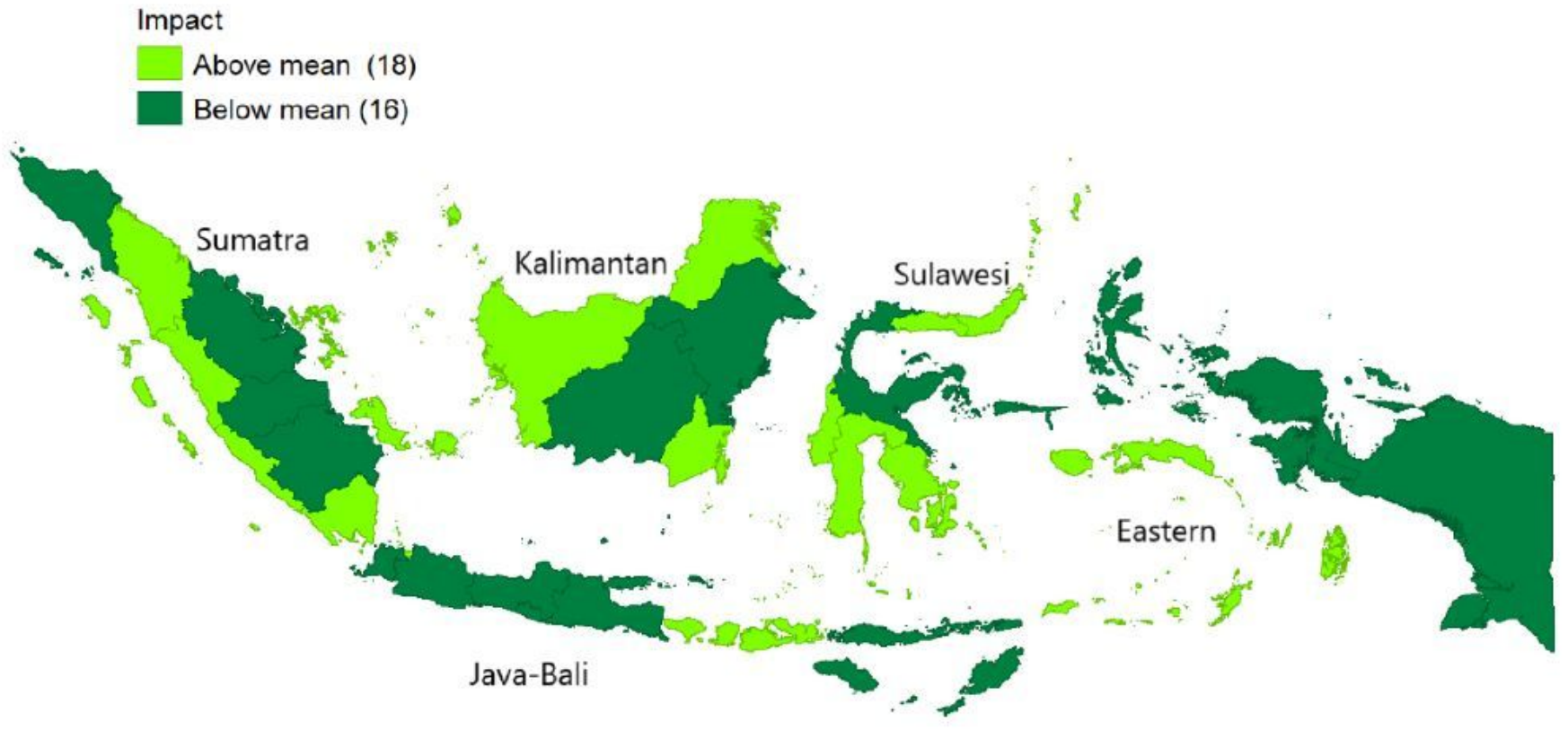

Figure 3

Geographical distribution of the regional inflation impact of a shock on policy rate Note: The designations employed and the presentation of the material on this map do not imply the expression of any opinion whatsoever on the part of Research Square concerning the legal status of any country, territory, city or area or of its authorities, or concerning the delimitation of its frontiers or boundaries. This map has been provided by the authors. 